\title{
Revisiting the restricted movement paradigm: the dispersal of Atlantic salmon fry from artificial redds
}

\author{
Zachary John Eisenhauer
}

\author{
A Thesis \\ In the Department \\ of
}

Biology

Presented in Partial Fulfilment of the Requirements

For the Degree of

Master of Science (Biology) at

Concordia University

Montreal, Quebec, Canada

May 2020

(C) Zachary John Eisenhauer, 2020 


\section{CONCORDIA UNIVERSITY}

\section{School of Graduate Studies}

This is to certify that the thesis prepared

By: $\quad$ Zachary Eisenhauer

Entitled: Revisiting the restricted movement paradigm: the dispersal of Atlantic salmon fry from artificial redds

and submitted in partial fulfilment of the requirements for the degree of

\section{Master of Science (Biology)}

complies with the regulations of the University and meets the accepted standards with respect originality and quality.

Signed by the final Examining Committee:

\begin{tabular}{cc}
\hline Dr. Dylan Fraser & Chair \\
\hline Dr. Ian Ferguson & External \\
\hline Dr. Grant Brown & Examiner \\
\hline Dr. Dylan Fraser & \\
\hline Dr. James Grant & Supervisor
\end{tabular}

Approved by:

Dr. Robert Weladji, Graduate Program Director

Date

2020

André G. Roy, Dean of Arts and Science 


\begin{abstract}
Revisiting the restricted movement paradigm: the dispersal of Atlantic salmon fry from artificial redds

Zachary John Eisenhauer
\end{abstract}

According to the restricted movement paradigm (RMP), salmonid fry should typically disperse less than $50 \mathrm{~m}$ upstream and $500 \mathrm{~m}$ downstream from nests or stocking locations. However, recent evidence of juveniles dispersing up to 1600 m suggests that the RMP may be oversimplified for juvenile Atlantic salmon. To test the RMP, we implanted 679997 eyed Atlantic salmon eggs (Salmo salar L.) into 19 artificial redds over six years in seven tributaries of a large river and then recovered fry via electrofishing to characterize their dispersal over their first summer of life. As expected, most fry dispersed downstream, but an average of $35 \%$ of fry moved upstream. Surprisingly, fry moved just as far upstream as downstream (medians $=403$ and $404 \mathrm{~m}$, respectively), with average maximum distances of $1.23 \mathrm{~km}$ and $2.14 \mathrm{~km}$, respectively. Fry were larger at lower densities and farther from redd sites, consistent with density-dependent growth. After controlling for density, however, fry were larger upstream than downstream, suggesting that larger fry move upstream compared to downstream. While there was variation among streams and years, kurtosis values were largely consistent with a normal distribution around the redd site, with only two of the 19 distributions being leptokurtic. Tributaries had even mixtures of mobile and stationary individuals, indicating a largely homogeneous movement strategy. Our data suggests that salmon fry were more mobile than previously thought, which should facilitate their stocking or reintroduction to new habitats. 


\section{Acknowledgments}

Several years ago, I was involved in a salmon recolonization project as a Biological Technician for the US Fish and Wildlife Service in Lake Champlain, situated between the Adirondack mountains in New York and the Green Mountains in Vermont. In the fall of the year, I met James Grant while walking down a dirt road next to a steep gorge on a tributary to the Winooski River. We were about to test new egg implanting equipment developed by a researcher working with the Maine Department of Marine Resources, his name was Paul Christman. There, Jim and I got to talking about the future of the Atlantic salmon restoration program in the Champlain Valley. Shortly into the discussion, the topic of grad school came up. The rest is history.

I thank Jim for giving me the opportunity to advance my career through this invaluable program, and I'd like to thank him for his unwavering patience, enthusiasm, and charisma. I would like to thank Dylan Fraser for being my unofficial co-supervisor, always ensuring that I had the resources I needed, and allowing me to attend his lab meetings. I thank him for giving me the opportunity to explore central Quebec with his post-doc and colleague on our search for pike with the Cree Nation; an opportunity that will never leave me. I hope to, one day, return again. I would like to thank my committee member Grant Brown. He always provided me with an open door and encouragement, even when I was at my worst.

I must thank my co-author Paul Christman for providing an amazing dataset after a failed field season and for his constant attention throughout this project. I thank my co-author JeanMichelle Matte for challenging me to learn the fine details of statistical analyses. Without him, I would not have learned as much as I did. I would also like to thank Oliver Cox from the Green Lake National Fish Hatchery for conducting the genetic crosses of the adult salmon used for this study and rearing the subsequent eggs to the eyed life-stage. Thank you to the field crews that 
participated in the Maine Department of Marine Resources Atlantic salmon restoration projects. Without them, I would have had no data to work with. I would like to thank all of my amazing lab members for their unwavering support throughout this journey. I am truly grateful to you all. Finally, I would like to thank my family, especially my wife, for their endless support during this challenging chapter of my life.

Partial funding of this report was provided by the U.S. Fish and Wildlife Service Award Number F16AC00243 to J. Grant and D. Fraser. Findings and conclusions are those of the authors and do not necessarily represent the views of the USFWS. 


\section{Contribution of Authors:}

Study concept and design: Eisenhauer, Grant, Fraser, Christman

Acquisition of data: Christman and Eisenhauer

Analysis and interpretation of data: Eisenhauer, Matte, Grant

Drafting of Manuscript: Eisenhauer

Critical revision: Eisenhauer, Grant, Fraser, Matte, Christman 


\section{Table of Contents}

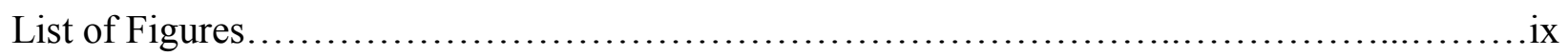

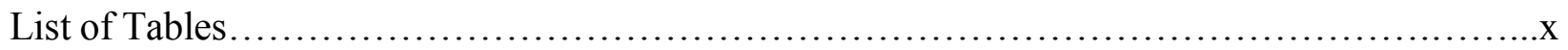

List of Supplementary Material............................................................

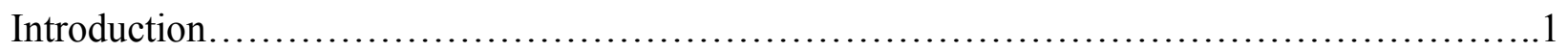

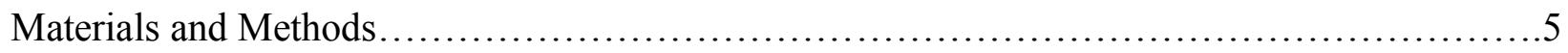

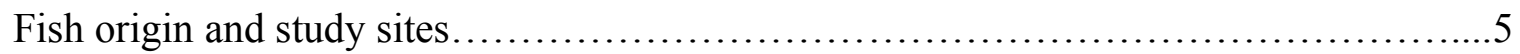

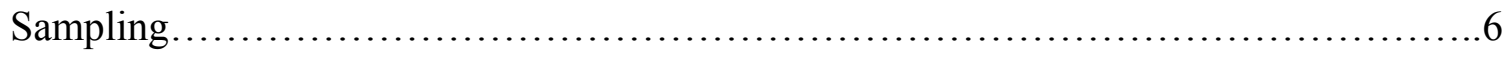

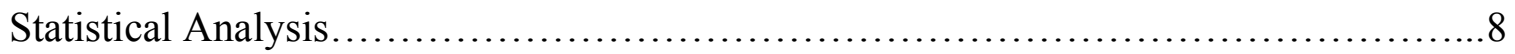

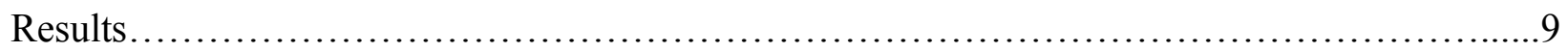

More fry disperse downstream than upstream.......................................9

Dispersal is farther downstream than upstream.....................................10

Downstream dispersal distance increases with increasing velocity or gradient...........10

Upstream dispersal distance decreases with increases in velocity and gradient..........10

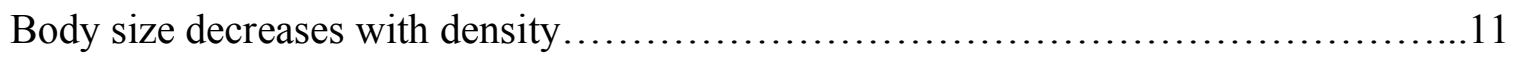

Fry will be larger upstream than downstream.....................................11

Heterogeneous vs homogeneous dispersal......................................11

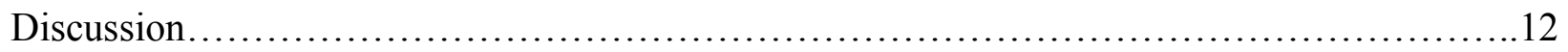

More fry disperse downstream than upstream...................................13

Fry dispersed great distances both downstream and upstream..........................14

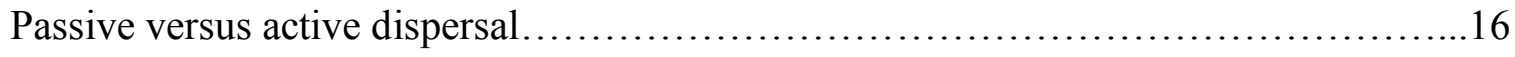

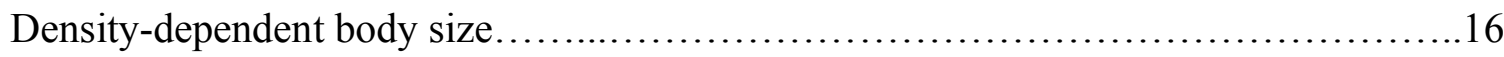

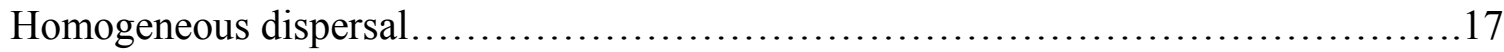


Caveats and recommendations...................................................... 17

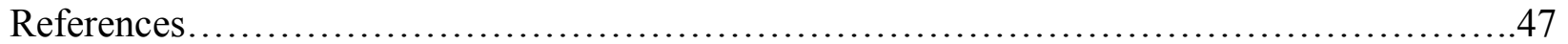




\section{List of Figures}

Figure 1. Map of six tributaries and Sandy River (confluence: 44.7643, -69.8895) in southwest Maine, USA................................................. 19

Figure 2. Density distributions of Atlantic salmon fry upstream and downstream (negative and positive, respectively) of each implant site (denoted by 0) in the Sandy River drainage. .20

Figure 3. Linear regression (with $95 \%$ confidence interval) of fork length (mm) of Atlantic salmon fry in relation to $\log _{10}$ of (A) density at each sampling site; and (B) distance from the redd site in the Sandy River drainage, separated by upstream (blue) and downstream (red) directions

Figure 4. Streams coloured by whether a one-parameter (red) or two-parameter (blue) model was selected using a theoretical equation described by Rodriguez (2002) .22

Figure 5. Violin graph illustrating the median (black dot) and maximum dispersal distance and the frequency of Atlantic salmon fry versus distance (m) from implant or redd location (zero distance) in upstream (negative numbers) and downstream directions. The upper and lower lines indicate 0 and $500 \mathrm{~m}$ downstream, respectively, the putative limits of dispersal in the literature. The thickness of the lines or bars represent higher densities. Bars above and below distributions represent different studies. 


\section{List of Tables}

Table 1. Description of seven streams used in the study of $0+$ Atlantic salmon fry dispersal in the Sandy River, ME, USA. All measurements calculated using USGS regression equations provided by the StreamStats Web-based Geographic Information Systems (GIS) application (Version: 4.3.8) .....................24

Table 2. Summary of Atlantic salmon fry movements (m) upstream (U) and downstream (D) from artificial redds in the Sandy River, Maine, USA and six tributaries from 20102018

Table 3. Multiple GLS regression results relating fry dispersal variable to a priori

predictors

Table 4. Comparison between a single- (stationary) or two- (mobile and stationary) parameter nonlinear equations (sensu Rodriguez 2002) to downstream dispersal distributions in seven Atlantic salmon populations. Kurtosis values are for each complete distribution (i.e. upstream and downstream) 


\section{List of Supplementary Material}

Supplementary Methods................................................................ 31

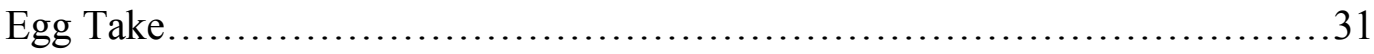

In-stream incubation system..................................................

Wild reproduction.............................................................33

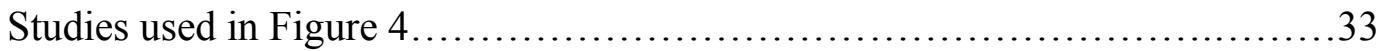

Figure S1. Insulated Styrofoam shipping container (right) used to transport eyed Atlantic salmon eggs from the Green Lake National Fish Hatchery to implant sites. One of six four-compartment trays (top left), used to stack eggs in the shipping container.

One wetted cheese cloth (bottom left), used to cover each tray ...................36

Figure S2. Maine Department of Marine Resources (MDMR) In-Stream Incubation System. Honda WX15 four stroke 49cc water pump (middle top), $3.1 \mathrm{~cm}$ diameter standpipe with a flexible hose (left), intake hose for pump with debris guard (middle bottom), and metal funnel for receiving standpipe and implanting eggs (right)............37

Figure S3. Schematic of the typical sampling plan. $\mathrm{D} \#=$ density estimate from CPUE electroshocking event. $\mathrm{N}_{\#}=$ Population estimate for shocking reach and distance between reaches. †Negative subscript denotes upstream position..................38

Figure S4. Histogram of Kurtosis values. Blue indicates the frequency of normal distributions; red indicates the frequency of leptokurtic distributions.

Table S1. Number and size of sampling sites in each stream. aArea reported in meters squared, width reported in meters........................................40

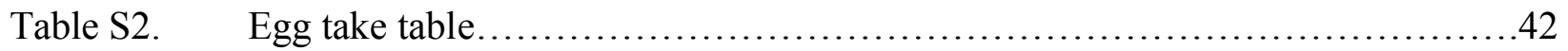

Table S3. Summary of wild Atlantic salmon activity in headwaters of Kennebec River.....44 
Table S4. Predictions about how environmental variables will affect Atlantic salmon fry dispersal. ${ }^{\alpha} \mathrm{SC}=$ Swimming capacity; $\mathrm{DD}=$ Density dependence ................45 


\section{Introduction}

The movement of individuals between habitats has important implications for metapopulation dynamics, gene flow, colonization of novel habitats, and recolonization of historic habitats (Vøllestad et al. 2012; Foldvik et al. 2017). More specifically, how an individual moves through its environment provides valuable information about what habitat types are important or its survival (Yeakel et al. 2018), and what cues prompt individuals to settle or disperse (Roy et al. 2013). From a management perspective, animal movement can confirm the success of habitat restoration projects, aid in determining the carrying capacity of a particular stream, and help to monitor and control the spread of invasive species (Šlapanský et al. 2020). Consequently, interest in the characterization of animal movements has increased in the past decade (Ronce 2007; De Bie et al. 2012; Clobert et al. 2012; Rasmussen and Belk 2017).

Traditionally, dispersal of animals has been modelled with simple geometric or exponential distributions (Porter and Dooley 1993; Turchin 1998). However, these models may over-simplify movement behaviour (Foldvik et al. 2017), given the differences and interactions between individuals (Ewers and Didham 2006; Drakou et al. 2009; Rasmussen and Belk 2017), and the temporal and spatial variability in the abiotic environment (Queller and Goodnight 1989; Vøllestad et al. 2012).

Stream fishes provide an ideal system for examining movement behaviour, as this movement can be quantified in a single dimension (e.g. upstream/downstream), which reduces model complexity and simplifies parameter estimations (Rodríguez 2002). It is widely accepted that stream fish are relatively sedentary, often living within in a single pool or a small stream reach - the restricted movement paradigm (RMP; Gerking 1959; Rodriguez 2002; Teichert et al. 2011; but see Gowan et al. 1994). When applied to stream salmonids (Gowan et al. 1994; 
Rodriguez 2002), the RMP suggests that stream salmonids spend most of their lives within short $(20-50 \mathrm{~m})$ stream reaches during non-migratory periods, such as the summer (e.g. Gowan et al. 1994). Even the movement of fry from redds, which should be an active dispersal phase to find suitable habitat in which to settle (Einum and Nislow 2005), is typically only at most $50 \mathrm{~m}$ upstream and $500 \mathrm{~m}$ downstream (Egglishaw and Shackley 1973; Egglishaw and Shackley 1980; Marty and Beall 1989; Beall et al. 1994; Crisp 1995; Einum et al. 2011). However, recent work has challenged the restricted fry dispersal paradigm by showing that some fry disperse downstream up to $1600 \mathrm{~m}$ from redds or stocking sites (Brodeur 2006; Webb et al. 2001; Radinger and Wolter 2014; Brunsdon et al. 2017). Furthermore, most studies quantifying salmonid fry dispersal draw conclusions from single redds or implant locations, from multiple locations but without temporal replication, or from spatial and temporal replication with censored data (Egglishaw and Shackley 1973; Marty and Beall 1989; Beall et al. 1994; Crisp 1995; Jokikokko 1999; Webb et al. 2001; Hudy et al. 2010; Einum et al. 2012; Vøllestad et al. 2012). For example, including more sampling effort downstream than upstream, or releasing fry below dams, waterfalls, or velocity barriers, could severely underestimate upstream dispersal and bias our understanding of the dispersal process.

To add an additional layer of complexity, populations may comprise varying mixtures of stationary and mobile individuals (Paradis et al. 1998; Gomez and Zamora 1999; Rodriguez 2002). These heterogeneous populations typically generate a leptokurtic frequency distribution of displacement distances, characterized by a higher central peak for stationary individuals and a larger tail with more frequent outliers than a normal distribution for mobile animals (Paradis et al. 1998; Gomez and Zamora 1999; Fraser et al. 2001; Radinger and Wolter 2014). Conversely, populations with homogeneous dispersal behaviour should have fewer and less extreme outliers, 
characterized as platykurtic (Skalski and Gilliam 2000). In stream salmonids, these stationary and mobile components have been modelled by the pattern of decline in the number of recaptured fry with the distance from their home section (Gowan et al. 1994). In a partial reconciliation of the RMP with the recently (see above) observed mobility of salmonid fishes, Rodriguez (2002) showed that high rates of dispersal from the home site are compatible with low total displacement. However, Rodriguez (2002) relied on data that included some adult lifestages and only included individuals moving a maximum of $400 \mathrm{~m}$. Due to the spatial ordering of mark-recapture studies, simple statistics are not sensitive to bimodalities (i.e. multiple lifestrategies), necessitating a more effective way for modelling dispersal (Rodríguez 2002).

Another challenge in characterizing fry dispersal is capturing the spatial and temporal variance among populations or regions. For instance, environmental factors such as gradient, water velocity, geographical location, and stochastic events can have a profound influence on dispersal due to varying swimming capacities amongst fry (Ottaway and Clarke, 1981; Elliott, 1994; Gowan et al. 1994). More specifically, higher gradients and water velocities could cause the passive dispersal of fry farther in the downstream direction (Heggenes and Dokk 2001; Yeakel et al. 2018). Such passive dispersal is often thought to be density independent (Einum and Nislow 2005; Foldvik et al. 2017).

Beyond environmental variation, regulatory processes such as density-dependence may also differ among populations (e.g. Matte et al, 2020). For example, fry may disperse to avoid the costs of density-dependent growth and mortality (Grant and Imre 2005; Grossman et al. 2012). Larger, dominant, or early emerging individuals may be more successful at establishing and defending territories near the redd, forcing less competitive individuals to disperse farther away (Elliott 1994). In this scenario, those closer to the redd would have higher fitness. 
Alternatively, individuals that disperse farther from the redd may reap the benefits of higher growth rates under lower densities (Einum et al. 2012).

To date, no study of stream salmonid dispersal has tested the predictions of the RMP while accounting for environmental factors or the spatial and temporal variation within and among streams, with respect to their dispersal curves. Hence, we conducted a field experiment across multiple tributaries, in which we implanted eyed eggs in historical spawning areas to characterize the full distribution of dispersing fry with spatial and temporal replication. We buried eyed eggs of Atlantic salmon across the Sandy River watershed in Maine, USA, and quantified the distribution of $0+$ juveniles upstream and downstream of 19 artificial redds. We tested the following predictions: [1] more fry will disperse downstream than upstream, and the percentage moving downstream will be higher in streams with higher flow or gradient; [2] fry will move farther downstream than upstream; [3] the distance moved downstream and upstream will increase and decrease, respectively, with increases in stream velocity and gradient; [4] fry body size will increase with dispersal distance in both directions, consistent with densitydependent growth; [5] after controlling for density, fry will be larger upstream than downstream, consistent with larger fry being able to move upstream against the flow; and [6] fry will exhibit heterogeneous dispersal behaviour within populations, resulting in leptokurtic distributions in relation to the redd site, and bimodal downstream dispersal distributions, following Rodriguez (2002). 


\section{Methods}

Fish origin and study sites

The study area encompassed most of the Sandy River and its six major tributaries in Maine, U.S.A., an area of 1536 km2 (Maine Department of Marine Resources 2014; hereafter MDMR; Fig. 1). The Sandy River descends $471 \mathrm{~m}$ to its confluence with the Kennebec River and comprises an excess of $2300000 \mathrm{~m} 2$ of Atlantic salmon rearing habitat (MDMR 2014). The local gradients (see below) ranged from $0.65-0.71 \%$ in the mainstem of the Sandy River, and $1.09-8.88 \%$ in the adjacent tributaries (Ries et al 2017).

A total of 679997 eyed Atlantic salmon eggs were planted in seven streams from 20102018 (see below, Table 1; Table S1), and the subsequent post emergence distributions were characterized. All the field work was completed by the Maine Department of Marine Resources before the onset of my thesis. Eggs were from the Penobscot River stock at the Green Lake National Fish Hatchery. The adults that produced our F2 eggs had one full generation in captivity. Sea-run adults were captured in the Penobscot River and held at Craig Brook National Fish Hatchery until spawning. Eyed eggs were moved to Green Lake National Fish Hatchery, where they were reared to adulthood (Fig. S1). Each year Green Lake spawns 500 or more families in waves as adult salmon mature, resulting in the spawning of as many as 297 females at one time $($ Mean $=110, \mathrm{SD}=78$; Table $\mathrm{S} 2)$. For more information on spawning, see Supplementary Methods.

The equipment used to bury the eggs was developed by the MDMR for large-scale Atlantic salmon restoration. For this project, we planted eggs $30 \mathrm{~cm}$ below the surface of the stream bed, within the normal range for Atlantic salmon (Bley 1987). When the depth was 
reached, the standpipe was removed, leaving the funnel in the gravel. Three to five hundred eggs were then poured underwater into the funnel (Fig. S2).

On average, 35789 eggs (range $=5350$ - 104 130; Table 2) were buried in a single artificial redd at densities ranging from 3200 - 8608 eggs/m2; the number of eggs was estimated from photos taken prior to planting. The location of each redd site was measured from its closest landmark and was identified by the distance measured in $\mathrm{km}$ from the confluence of the next downstream river following the drainage; e.g. Sandy River $73.73 \mathrm{~km}$ was $73.73 \mathrm{~km}$ upstream of the confluence of the Kennebec River. We chose sites that were ideal spawning habitat for Atlantic salmon, typically large shallow gravel shoals (Loui et al. 2008), easily accessible by road, and surrounded by continuous reaches of high-quality rearing habitat (sensu Armstrong et al. 2003; Girard et al. 2003).

It was unlikely that wild fry affected our data. In annual redd surveys from 2010-18, a total of 85 wild redds were found in the Kennebec watershed (Table S3). Only one wild redd was ever found within $11 \mathrm{~km}$ of an implant site; it was $0.4 \mathrm{~km}$ upstream of the implant site on Perham stream in 2014 (Table S3). However, no fry were captured at that location during surveying, indicating the redd was likely unsuccessful or abandoned before fertilization.

Sampling

Electrofishing (Smith-Root LR-24) for 0+ fry focused on representative sites that were upstream and downstream from the implant sites. Sampling was conducted between the first week of August and the first week of September by a crew of 2 to 3 people. On average, there were 8.6 sampling sites (mean length $=15.4 \mathrm{~m}, \mathrm{SD}=6.67 \mathrm{~m}$, range $=3.7-33.2 \mathrm{~m}$ ) surrounding each redd, with 5.2 sites downstream $(\mathrm{SD}=1.96$, range $=2-9$; Table $\mathrm{S} 1)$ and 3.4 sites upstream 
$(\mathrm{SD}=1.98$, range $=1-8)$ for a total sampling area of $998.4 \mathrm{~m} 2(\mathrm{SD}=392.62 \mathrm{~m} 2$, range $=437-1$ $607.64 \mathrm{~m} 2$; see Table $\mathrm{S} 1)$.The mean distance between sampling sites was $394.1 \mathrm{~m}(\mathrm{SD}=257.8$ $\mathrm{m}$, range $=50-1620 \mathrm{~m})$, spread over a mean length of stream of $1145.3 \mathrm{~m}$ upstream $(\mathrm{SD}=1$ $236.16 \mathrm{~m}$, range $=60-4770 \mathrm{~m})$ and $2063.68 \mathrm{~m}$ downstream $(\mathrm{SD}=1233.13 \mathrm{~m}$, range $=780-4$ $790 \mathrm{~m}$ ). Each site was sampled with a single pass, without blocking nets, totalling $300 \mathrm{~s}$ of electrofishing. Sampling continued in an outward direction in both directions from the planting site until fewer than three $0+$ parr were captured at a site. All fish captured were counted, measured and weighed (Fig. S3). Age class was assigned by fork length, with mean size of 0+ fry of $55.4 \mathrm{~mm},(\mathrm{SD}=7.40 \mathrm{~mm})$. Less than $1 \%$ of all parr were thought to be age $1+$, so any misclassification was unlikely to affect our analyses.

To estimate the number of fry that survived from each redd, the total number of fry captured per site was first divided by 0.64 , the average catchability for fry (P. Christman, unpublished data), somewhat higher than what is found in other studies (Niemelä et al. 2000), but is not uncommon (Hedger 2018). The density per site (i.e. m-2) was used to estimate the density and number of $0+$ fry for the area of the stream halfway to the next sampling site in both directions (Fig. S1). Percent egg to $0+$ fry survival was calculated by dividing the estimated number of fry around (see Fig. S1) each implant site by the number of eggs planted.

We used two measures of the gradient of the stream (percent rise - run-1): (i) local gradient, for the length of stream in which fry were found; and (ii), stream gradient, for the entire stream from the headwaters to its confluence. Stream gradient was included to incorporate watershed effects on fry dispersal, such as how high mountain peaks might affect snow-pack runoff, water temperature, and current velocities. Local gradient was determined using ArcGIS 
(version 10.7.0.10450), whereas stream gradient was determined using regression equations generated in USGS StreamStats GIS database (version 4.3.8).

\section{Statistical Analysis}

We used paired $t$-tests to compare the proportion and median dispersal distance of fish moving upstream and downstream from redd implant locations. Then, generalized least square regressions (GLS) were used to quantify the impact of demographic and environmental variables on the proportion of fish moving upstream, median dispersal distance, and fish body length. GLS models were used to account for important heterogeneity of variance across streams. The most parsimonious models were selected using backwards model selection with AICc (Burnham and Anderson 2004; Zuur et al. 2010). Collinearity was assessed with the variance inflation factor (VIF) before model selection. Kurtosis was also used to describe the shape of the complete (i.e. upstream and downstream) dispersal distributions: values near 0 were considered mesokurtic, whereas values larger than 3 and smaller than -3 were considered leptokurtic and platykurtic, respectively. These threshold values $(-3,3)$ were used given our relatively large sample size (George and Mallery 2010). The methodology described by Rodriguez (2002) was used to investigate whether each stream's dispersal distribution in the downstream direction only could be best explained by single or two parameter non-linear equations. For homogeneous dispersal, the single parameter equation is defined as:

$$
f(x)=\lambda \mathrm{e}^{-\lambda x}
$$

where $f(x)$ is a dispersal function relating the decline in density with distance, $x$ is the distance $(\mathrm{m})$, and $\lambda(\mathrm{m}-1)$ is the inverse of mean displacement distance. However, with heterogeneous dispersal behaviour within a population, dispersal is best described by a two parameter equation: 


$$
f(x)=p \lambda_{S} \mathrm{e}^{-\lambda_{S} \mathrm{x}}+(1-p) \lambda_{m} \mathrm{e}^{-\lambda_{m} \mathrm{x}}
$$

where $\lambda_{s}$ and $\lambda_{m}$ represent the stationary and mobile components, respectively, $p$ represents the proportion of stationary individuals and $1-p$ represents the proportion of mobile individuals.

Both single and two parameter models were fit to each distribution, after which their respective performance were compared using AICc.

\section{Results}

A mean density of 22.7 fry $\cdot 100 \mathrm{~m}-2(\mathrm{SD}=42.57$, range $=0-333.8)$ were captured at the 173 electrofishing sites. When these densities were prorated to the entire stream reaches, we estimated a total of 125650 fish survived until sampling, or 18.5\% of the 679997 eggs that were planted (mean $=22.0 \%, \mathrm{SD}=18.3$, range $=2.5-78.0$ ). While the patterns of dispersal varied widely among streams, there appeared to be some consistent patterns within streams over years (Fig. 2, see below).

\section{Prediction 1: More fry disperse downstream than upstream}

As expected, significantly more fish moved downstream than upstream (Table 2; paired ttest: $\left.t_{18}=3.75, p=0.00146\right)$. However, the percentage of fry moving upstream varied considerably from a low of $0 \%$ in Orbeton Stream to a high of $68.5 \%$ in Cottle Brook (mean $=$ 34.5, $\mathrm{SD}=18.06$; Table 2; Fig. 2). In contrast with expectations, the percentage of fish moving upstream was not correlated with any of the predicted environmental parameters (all $P$-values $>$ 0.2; Table 3A); these results were supported by the null model having the lowest AICc value during model selection $(\triangle \mathrm{AICc}=4.71$; Table $3 \mathrm{~A})$. 


\section{Prediction 2: Dispersal is farther downstream than upstream}

In contrast to the prediction, median fry dispersal distance was not farther downstream than upstream (paired t-test: $\mathrm{t}_{18}=-0.004 \mathrm{df}=18, p=0.997$ ); the average median dispersal distance downstream (mean $=403.7 \mathrm{~m}, \mathrm{SD}=286.7 \mathrm{~m}$, range $=60-1280 \mathrm{~m}$; Table 2) was similar to upstream $($ mean $=403.2 \mathrm{~m}, \mathrm{SD}=476.3 \mathrm{~m}$, range $=0-1600 \mathrm{~m})$. The mean maximum distance dispersed upstream and downstream was 1.23 and $2.14 \mathrm{~km}$, respectively, farther than a maximum of $500 \mathrm{~m}$ downstream $\left(\mathrm{t}_{18}=5.60, p=0.00002\right)$ or $50 \mathrm{~m}$ upstream $\left(\mathrm{t}_{18}=4.01, p=\right.$ 0.0007) predicted by the RMP.

Prediction 3a: Downstream dispersal distance increases with increasing velocity or gradient

Opposite to the predictions, median downstream dispersal distance decreased with increasing velocity $\left(\mathrm{t}_{16}=8.49, p<0.0001\right)$ and stream gradient $\left(\mathrm{t}_{16}=7.46, p<0.0001\right.$; Table 3B). As predicted, however, maximum downstream dispersal distance increased with increasing velocity ( $\left.\mathrm{t}_{16}=5.90, p<0.0001\right)$ and with body length $\left(\mathrm{t}_{16}=17.58, p<0.0001\right)$. Contrary to predictions, gradient had no significant effect on maximum upstream or downstream dispersal distance (Table 3C).

Prediction 3b: Upstream dispersal distance decreases with increases in velocity and gradient Median upstream dispersal distance was not affected by gradient or velocity but did increase with body size $\left(\mathrm{t}_{17}=31.46, p<0.0001\right.$; Table 3D). However, maximum upstream dispersal distance decreased with increasing stream velocity $(\mathrm{t} 16=19.16, p<0.0001$; Table $3 \mathrm{E})$, increased with body size $\left(\mathrm{t}_{16}=27.81, p<0.0001\right.$; Table $\left.3 \mathrm{E}\right)$, but was not affected by stream gradient (Table 3E). 


\section{Prediction 4: Body size decreases with density}

Model selection indicated that water velocity, egg mortality, distance from the redd, direction, and population density (Table 3F) had independent effects on mean body length. As predicted, mean body length (mean $=57.5 \mathrm{~mm}, \mathrm{SD}=4.8 \mathrm{~mm}$ ) decreased with increasing density ( $\mathrm{t}_{16}=4.43, p<0.0001$; Fig. 3a), consistent with density-dependent growth. However, there was also an independent effect of distance from the implant location, consistent with the prediction that larger fish moved farther $\left(\mathrm{t}_{16}=6.19, p<0.0001\right.$; Fig $\left.3 \mathrm{~b}\right)$.

\section{Prediction 5: Fry will be larger upstream than downstream}

Independent from the density effect, fish were significantly larger upstream than downstream $\left(\mathrm{t}_{16}=5.04, p<0.0001\right)$, consistent with the prediction that larger fish are able to move upstream more easily than smaller fish. While controlling for stream, model selection indicated that median upstream dispersal distance increased with body length $\left(\mathrm{t}_{16}=31.46, p<\right.$ 0.0001). Body size also increased with percent egg mortality ( $\left.\mathrm{t}_{16}=8.30, p<0.0001\right)$, suggesting a higher mortality rate for smaller fish. Unexpectedly, body size also increased with water velocity ( $\left.\mathrm{t}_{16}=3.15, p=0.002\right)$, perhaps an indication of more food (i.e. drifting invertebrates) available in faster rivers.

Prediction 6: Heterogeneous vs homogeneous dispersal

Values of kurtosis varied among streams (range $=-1.27$ to 4.76 ; Table 4): of the 19 distributions, 17 were not significantly different from a normal distribution (i.e. mesokurtic; kurtosis values between -3 and 3), 2 were leptokurtic (high-peaked, long tails; value $>3$ ) and none were platykurtic (low-peaked, short tails; value $<-3$; see Fig. S4). Contrary to predictions, 
no streams were consistently leptokurtotic over years, evidence against heterogeneity in dispersal behaviour within streams.

Sixteen distributions had sufficient data to test for a one- versus two-parameter downstream dispersal curve; three distributions were excluded because they had fewer than four observations. Despite the paucity of leptokurtic distributions, only eight downstream distributions were best described by a single-parameter model (i.e. only a stationary component, Table 4), whereas eight were best described by a two-parameter model (i.e. both mobile and stationary components, Table 4). Two-parameter models were characterized by lower densities around the implant site, with a second peak of density farther from the implant site (Fig. 4). Alternatively, one-parameter models were characterized by high densities around the implant site and the absence of a second peak in density.

Whether a stream was best described by a one- versus two-parameter model was somewhat consistent across years (Chi-square: $\left.\chi^{2} 16=5.025, p=0.087\right)$. More specifically, twoparameters were selected in four of five years in Mt. Blue and three of four years in Temple, whereas Sandy River was best explained by a single-parameter model in all 3 years (Table 4, Fig. 4).

\section{Discussion}

Collectively, our results for Atlantic salmon fry do not support the Restricted Movement Paradigm as applied to the dispersal of salmonid fry from a nest or stocking site. We observed fry moving large distances in both the upstream and downstream directions, in multiple streams. Fry were larger at the lower densities farther from redds, and upstream than downstream, consistent with density-dependent growth and with larger fish being better able to disperse 
upstream, respectively. However, downstream dispersal was inversely related with velocity and stream gradient, contrary to the passive dispersal hypothesis (Elliott 1966; Marty and Beall 1989; Hesthagen 1988; but see Ottaway and Clarke 1981). Only two of 19 dispersal distributions were leptokurtic, suggesting that most streams comprised a homogenous population of somewhat mobile individuals. When we considered downstream dispersal only, there was evidence of a bimodal population of dispersers in half of the streams.

\section{More fry disperse downstream than upstream}

Compared with past studies (e.g. Egglishaw and Shackley 1973; Egglishaw and Shackley 1980; Beall et al. 1994; Crisp 1995; Marty and Beall 1989; Einum et al. 2011), a much higher proportion of fry (35\%), moved upstream in our study. In contrast, the mean percentage moving upstream in the other studies (Fig. 5) was only $12.4 \%(\mathrm{SD}=16.25 \%$, range $=0$ to 51.4\%). Egglishaw and Shackley (1973) may have had a higher percentage of fry moving upstream due to the placement of fry between a deep gorge (downstream) and a waterfall (upstream).

While none of our environmental variables could explain differences among streams in this tendency for upstream dispersal, there was some consistency in streams over years. For example, Perham stream had the highest consistent upstream dispersal with 44, 44.1, and 51.6\% over years. In contrast, Sandy River had 18.7, 21.9, and 36.1\% moving upstream over the years sampled. We can only surmise that our stocked fry were responding to some un-measured variable to produce such consistent behaviour over years.

We suspect that the low percentage of upstream dispersal detected in previous studies may have been due to an unconscious or deliberate censoring of upstream movement. For 
instance, the first study to show that fry dispersal is primarily downstream was likely Elliott (1966), followed by Egglishaw and Shackley (1973), and then Mary and Beall (1989). All of these studies had inherent downstream biases. After these studies, it became common practice to stock or implant fry at the upstream end of a section of fast-flowing water or immediately downstream of waterfalls or dams (e.g. Beall et al.1994; Crisp 1995; Brunsdon et al. 2017).

\section{Fry dispersed great distances both downstream and upstream}

Our results demonstrate large-scale median dispersal distances both upstream (403 m) and downstream (404 m) (Fig. 3a, 5), far greater than the predictions of RMP for this life stage (10 and $50 \mathrm{~m}$, respectively). Surviving fry that disperse far from the redd could have major implications for gene flow and colonization of new or historic habitat (Crisp 1995; Fraser et al. 2001; Yeakel et al. 2018). More specifically, dispersal away from the redd contributes to genetic rescue, species resilience and stability, and other connections within meta-populations, in which salmonid populations thrive (Gilbert 2016; Yeakel et al. 2018).

It is possible the large dispersal distances in our study were due to the stock used for implanting, which were not locally adapted to the region. Fitness and survival of Atlantic salmon is greatly reduced when they are reared in a hatchery (Araki et al. 2008; Milot et al. 2013;

Dittman et al. 2015), and the rate of stray is increased (Jonsson et al. 2003, Dittman et al. 2015). However, other studies suggesting restricted movement also used hatchery fish (Egglishaw and Shackley 1973; Gustafson-Greenwood and Moring 1990; Beall et al. 1994; Crisp 1995; Einum and Nislow 2005; Einum et al. 2012), or implanted wild stock from another river (Marty and Beall 1989). A difference in river size could also have influenced the distance dispersed, but we 
included a wide range of river sizes (6.7-64.9 $\mathrm{m}$ in width; Table 1), all of which had tremendous dispersal distances (Table 2).

Dispersal behaviour observed in this study might be partially due to habitat quality in the watershed or at the sites where eggs were initially deposited. Habitat can have a major influence on the movement and behaviour of Atlantic salmon (Heggenes 1990), and quality is on the decline in many areas (Jelks et al. 2008). Habitat that was suitable in the fall after being selected and excavated by the female parent could be unsuitable for rearing at the time of emergence, necessitating a higher-than-average upstream (and/or downstream) dispersal (Heggenes 1990). Similarly, the sites selected for implanting may have appeared ideal, but were suboptimal for emerging fry. We think poor habitat quality is an unlikely explanation for our results for two reasons. First, implant sites were selected based on historical spawning areas (P. Christman, unpublished data). Second, the estimated average survival rates of $22 \%$ compared favourably to previous studies showing restricted movement (Crisp 1995).

Previous study designs have made it difficult to characterize the spatial extent and probability of upstream movement and have likely increased the potential for unnatural behaviour, such as forced dispersal events by implanting fish immediately downstream of barriers or unsuitable habitat (Fig. 5). Nevertheless, the variability in dispersal distance observed between studies (Fig. 5) suggests that other factors are at play, such as the effects of local environmental conditions or local adaptation of populations. For example, intense predation on dispersing fry combined with a prior resident advantage to early emerging fry could lead to the restricted movement of fry (Einum et al. 2012). 


\section{Passive versus active dispersal}

At first glance, downstream dispersal distance seemed to be active rather than passive median downstream dispersal decreased in streams with higher velocities and gradients, suggesting that fish were choosing to settle sooner in adverse conditions. However, maximum downstream dispersal increased with gradient/velocity and body size, consistent with the passive-dispersal and active-swimming hypotheses, respectively. In summary, no clear picture of what drives downstream dispersal distance emerged, but something other than just swimming capacity was likely important (Ottaway and Clarke 1981).

In contrast to downstream dispersal, upstream dispersal distance was consistent with the active dispersal hypothesis. Both median and maximum distance increased with body size and maximum distance decreased with increasing stream velocity. Furthermore, fish were larger upstream than downstream, suggesting that larger fish were better able to swim upstream against the current.

\section{Density-dependent body size}

Consistent with density-dependent growth (Grant and Imre 2005), fry were larger at lower densities. However, the independent effect of distance from the implant site suggests that larger fish disperse farther (see above). The larger size of fry in streams with faster flows suggests a higher abundance of drifting invertebrates in larger, faster streams. These results highlight the possible advantage afforded to the individuals capable of moving away from the redd or implant location, especially if it is in the upstream direction. 


\section{Homogeneous dispersal}

Persistent leptokurtosis and bimodal dispersal curves suggest population heterogeneity in movement behaviour (Paradis et al. 1998; Gomez and Samora 1999; Skalski and Gilliam 2000; Fraser et al. 2001; Radinger and Wolter 2014). In contrast to previous studies, our results suggested relatively homogeneous behaviour: few dispersal curves were leptokurtic and only half of downstream distributions were bimodal. If heterogeneity is a response to divergent selection pressures in the wild (Skalski and Gilliam 2000; Fraser et al. 2001), then it is possible that the selective regime acting in the hatchery is responsible for the homogeneous behaviour observed in our study. Other stocked populations, however, have also exhibited heterogeneous behaviour, consisting of both mobile and stationary individuals (Rodriguez 2002)

While heterogeneity in dispersal is thought to contribute to gene flow, a mixture of mobile and stationary individuals can still follow the RMP (Rodriguez 2002). At the time, the maximum spatial extent for Atlantic salmon was only $346 \mathrm{~m}$, much less than the $4770 \mathrm{~m}$ in our study or in Brunsdon et al. (2017). Our results suggest less heterogeneity within populations, but greater overall mobility that should promote gene flow and the colonization of empty habitats. Taken together with past studies, our results highlight the potential for greater variability in movement behaviour between Atlantic salmon populations than previously thought, which has implications for the management of this important species.

\section{Caveats and recommendations}

We deposited more eggs in each artificial redd than would normally be found in natural redds (see Table 2). However, we think these higher densities cannot explain the large dispersal distances observed here. First, the lower range of eggs in our study were similar to what would 
be found in a natural redd (Reid and Chaput 2012). Second, there was no effect of egg density on median dispersal distance. Third, the growth rate and estimated survival rate in our study were high compared to other studies (e.g. Brunsdon et al. 2018), suggesting no adverse effects of the high initial densities.

Many studies that have previously quantified salmonid fry dispersal placed artificial redds or released stocked fish downstream of a barrier, such as a waterfall, dam, or zone of fast water (Egglishaw and Shackley 1973; Crisp 1995). Hence, such studies could not effectively describe the magnitude of upstream movement at this early life stage (Marty and Beall 1989, Beall et al. 1994). The downstream dispersal observed in these early, influential studies may have unconsciously biased later studies to focus most of their sampling efforts downstream rather than upstream (e.g. Jokikokko 1999; Einum et al. 2011; Brunsdon et al. 2017).

Quantifying the complexity of Atlantic salmon fry dispersal can help us understand the correlates of fitness, habitat use, the mechanisms driving movement, and can help to identify patterns connecting source and sink populations. Researchers and managers should not necessarily assume that restricted movement always applies to the fry life stage. Rather, patterns of dispersal may vary on a per stream basis. A formal synthetic analysis may be required to explore the variability among studies and the degree to which potential biases influence our understanding of this important phase of the life history of stream salmonids. 


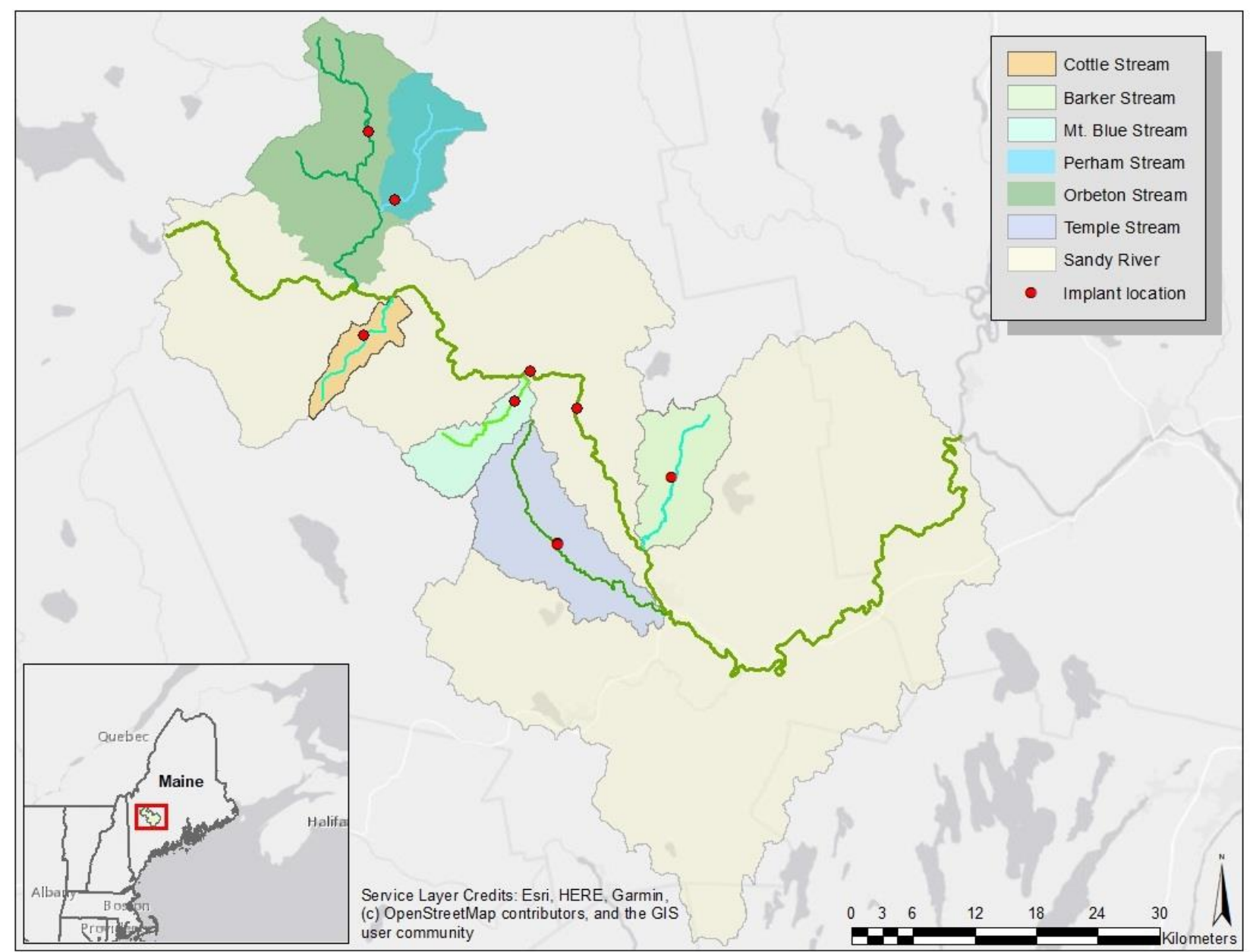

Figure 1. Map of six tributaries and Sandy River (confluence: 44.7643, -69.8895) in southwest Maine, USA. 


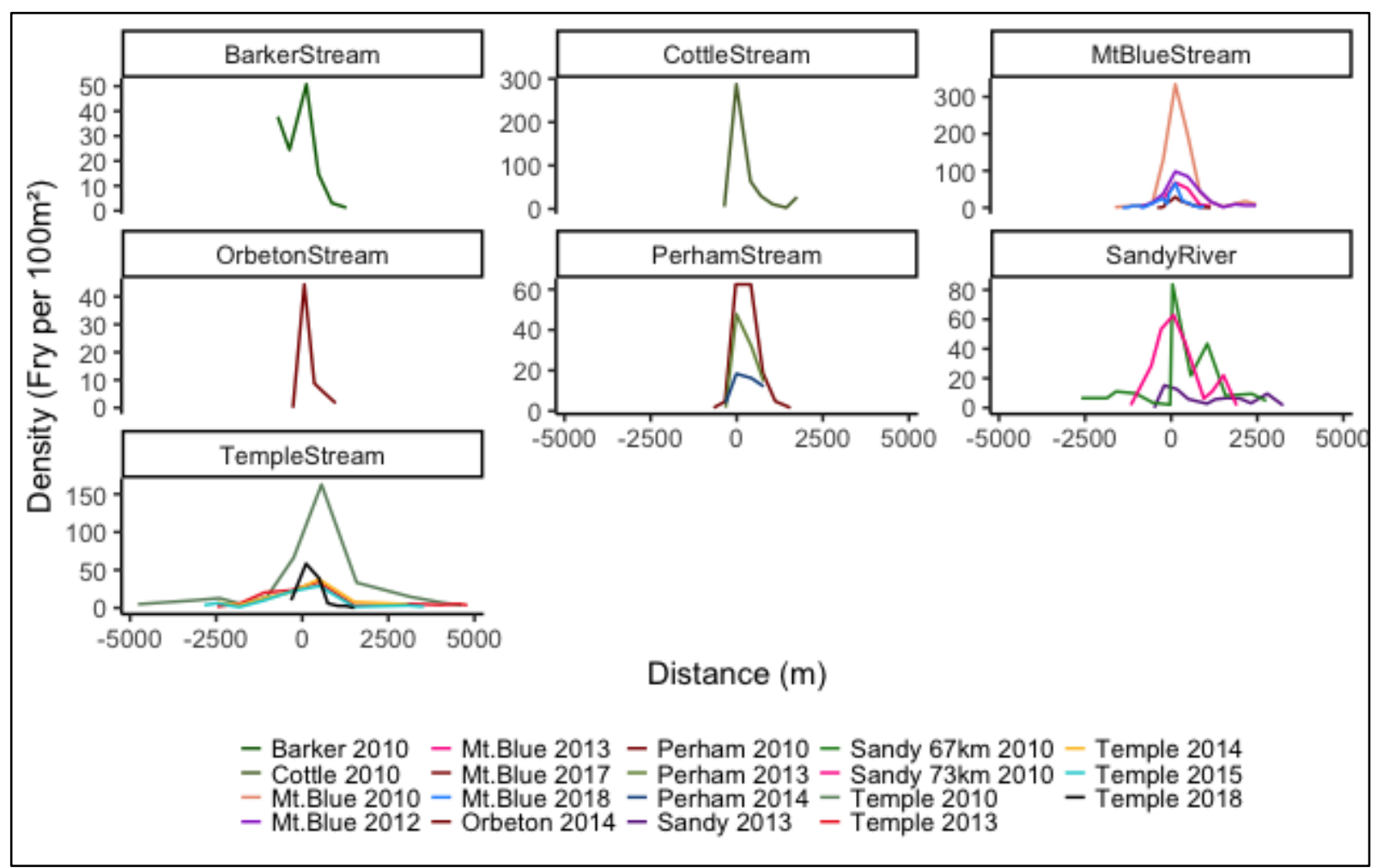

Figure 2. Density distributions of Atlantic salmon fry upstream and downstream (negative and positive, respectively) of each implant site (denoted by 0) in the Sandy River drainage. Note the y-axes have different scales. 


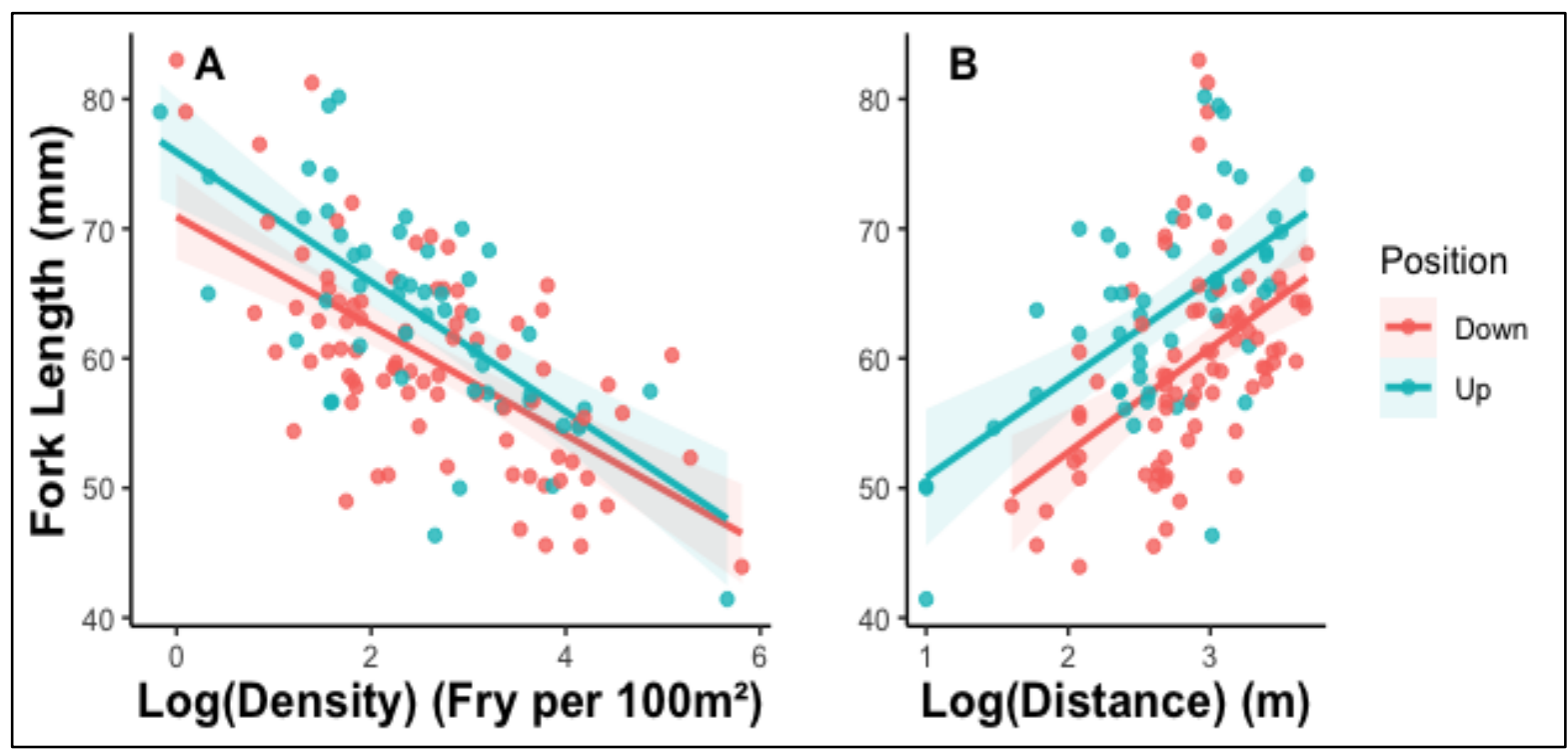

Figure 3. Linear regression (with $95 \%$ confidence interval) of fork length (mm) of Atlantic salmon fry in relation to $\log 10$ of $(\mathbf{A})$ density at each sampling site; and (B) distance from the redd site in the Sandy River drainage, separated by upstream (blue) and downstream (red) directions. 


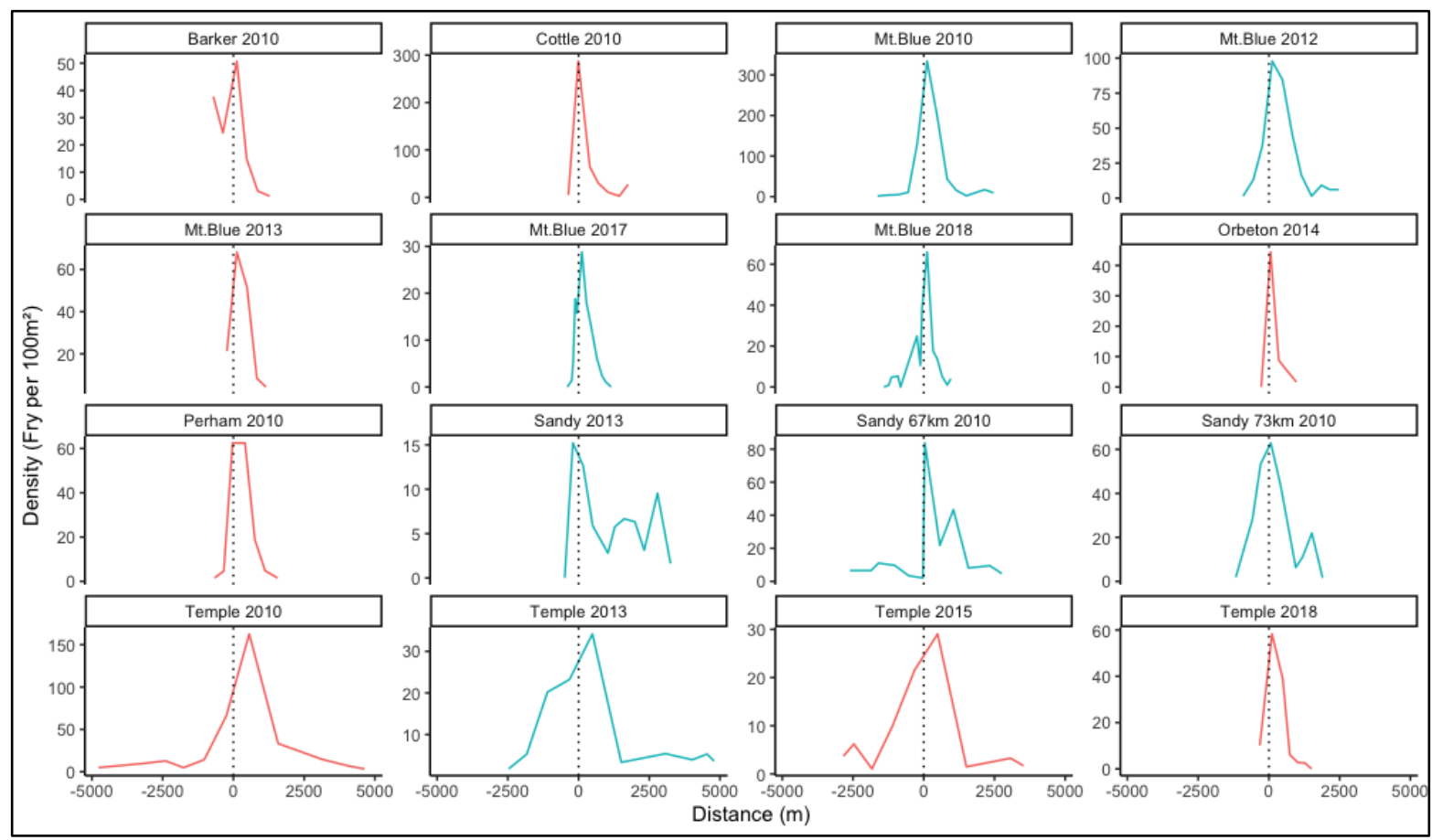

Figure 4. Streams coloured by whether a one-parameter (red) or two-parameter (blue) model was selected using a theoretical equation described by Rodriguez (2002). Note the y-axes have different scales. 


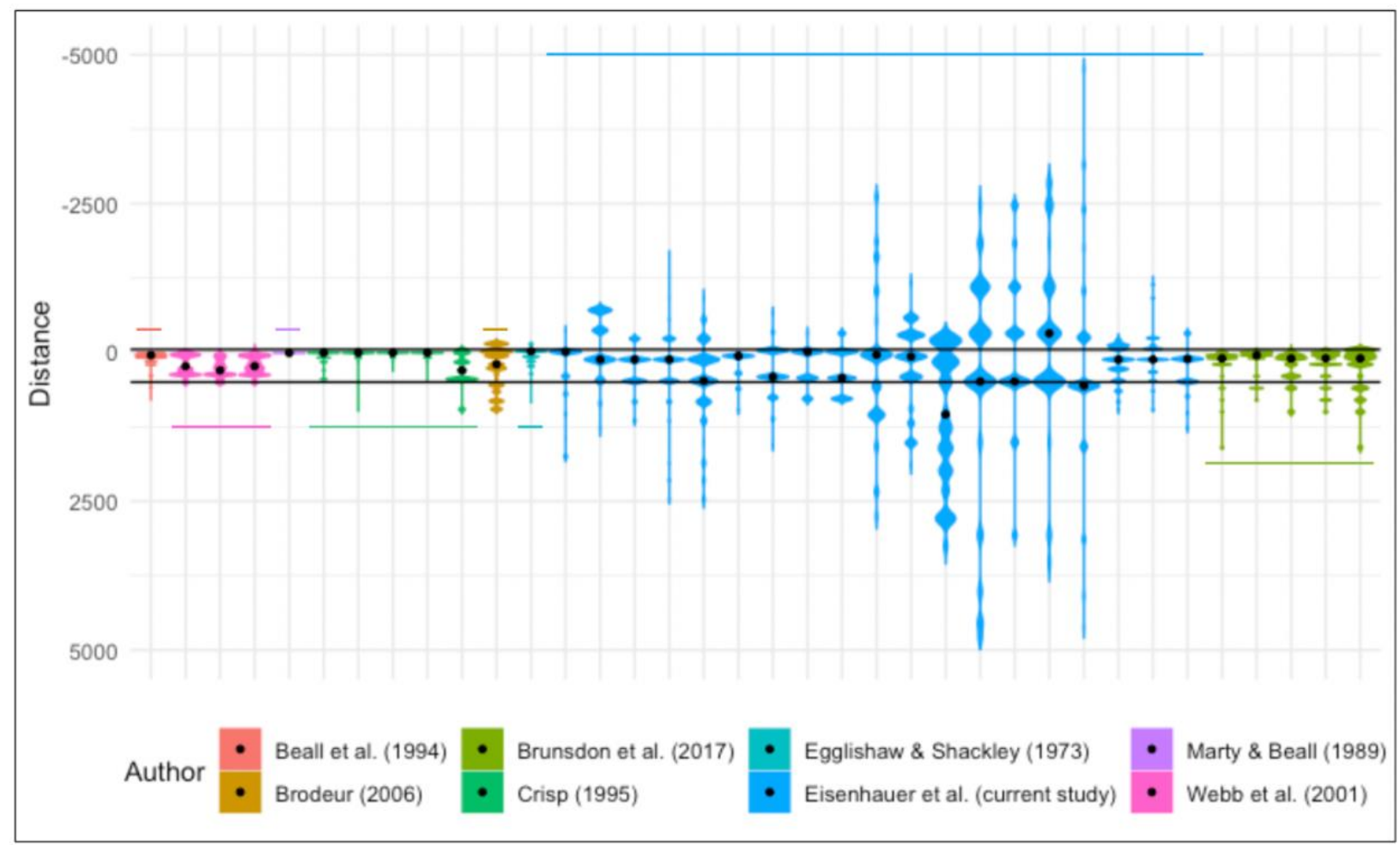

Figure 5. Violin graph illustrating the median (black dot) and maximum dispersal distance and the frequency of Atlantic salmon fry versus distance $(\mathrm{m})$ from implant or redd location (zero distance) in upstream (negative numbers) and downstream directions. The upper and lower lines indicate 0 and $500 \mathrm{~m}$ downstream, respectively, the putative limits of dispersal in the literature. The thickness of the lines or bars represent higher densities. Bars above and below distributions represent different studies. 
Table 1. Description of seven streams used in the study of 0+ Atlantic salmon fry dispersal in the Sandy

River, ME, USA. All measurements calculated using USGS regression equations provided by the StreamStats Web-based Geographic Information Systems (GIS) application (Version: 4.3.8).

\begin{tabular}{|c|c|c|c|c|c|c|}
\hline Name & Drainage & Average & Mean Basin & Basin Elevation & Years & Coordinates $\%$ \\
\hline & Area $\left(\mathrm{km}_{2}\right)$ & Width (m) & Slope $(\%)$ & Mean; Max (m) & Sampled & \\
\hline Mt Blue Stream & 31.1 & 8.5 & 17.0 & $431.8 ; 973.0$ & 5 & $44.8036,-70.2715$ \\
\hline Temple Stream & 87.0 & 14.5 & 15.4 & $989.7 ; 792.4$ & 5 & $44.6541,-70.1472$ \\
\hline Perham Stream & 40.7 & 9.8 & 16.2 & $651.5 ; 1234.7$ & 3 & $44.9049,-70.3967$ \\
\hline Orbeton Stream & 153.8 & 19.5 & 17.0 & $594.1 ; 1259.2$ & 1 & $44.8559,-704176$ \\
\hline Sandy River & 1541 & 64.9 & 11.8 & $286.5 ; 1259.2$ & 3 & $44.7643,-69.8895$ \\
\hline Cottle Brook & 19.7 & 6.7 & 13.5 & $386.9 ; 768.7$ & 1 & $44.8510,-70.3872$ \\
\hline Barker Stream & 50.0 & 10.9 & 12.4 & $232.8 ; 612.9$ & 1 & $44.6954,-70.1662$ \\
\hline
\end{tabular}


Table 2. Summary of Atlantic salmon fry movements (m) upstream (U) and downstream (D) from artificial redds in the Sandy River, Maine, USA and six tributaries from 2010-2018.

\begin{tabular}{|c|c|c|c|c|c|c|c|c|c|c|}
\hline \multirow[t]{3}{*}{ Stream } & \multirow[t]{3}{*}{ Year } & \multirow{3}{*}{$\begin{array}{c}\text { Eggs } \\
\text { Implanted }\end{array}$} & \multirow{3}{*}{$\begin{array}{l}\text { Percent* } \\
\text { Recovered }\end{array}$} & \multicolumn{2}{|c|}{ Mean distance } & \multirow{2}{*}{\multicolumn{2}{|c|}{$\begin{array}{l}\text { Median } \\
\text { distance }\end{array}$}} & \multirow{2}{*}{\multicolumn{2}{|c|}{$\begin{array}{l}\text { Maximum } \\
\text { distance }\end{array}$}} & \multirow{3}{*}{$\begin{array}{l}\text { Percent } \\
\text { Upstream }\end{array}$} \\
\hline & & & & \multirow[t]{2}{*}{$\mathrm{U}$} & \multirow[t]{2}{*}{$\mathrm{D}$} & & & & & \\
\hline & & & & & & $\mathrm{U}$ & $\mathrm{D}$ & $\mathrm{U}$ & $\mathrm{D}$ & \\
\hline Baker Stream & 2010 & 5825 & 18.54 & 576.5 & 247.1 & 710 & 120 & 710 & 1280 & 47.1 \\
\hline Cottle Brook & 2010 & 42500 & 9.87 & 15.9 & 811.9 & 10 & 700 & 360 & 1750 & 68.5 \\
\hline Mt. Blue & 2010 & 51457 & 45.87 & 313.2 & 431.2 & 230 & 120 & 1630 & 2470 & 19.4 \\
\hline \multicolumn{11}{|l|}{ Stream } \\
\hline Mt. Blue & 2012 & 28780 & 30.24 & 330.9 & 586.3 & 230 & 480 & 910 & 2470 & 16.4 \\
\hline \multicolumn{11}{|l|}{ Stream } \\
\hline Mt. Blue & 2013 & 28442 & 14.93 & 230 & 338.6 & 230 & 120 & 230 & 1150 & 13.9 \\
\hline \multicolumn{11}{|l|}{ Steam } \\
\hline Mt. Blue & 2017 & 4968 & 25.09 & 110.3 & 309.8 & 120 & 280 & 240 & 960 & 37.8 \\
\hline \multicolumn{11}{|l|}{ Stream } \\
\hline Mt. Blue & 2018 & 5350 & 77.98 & 246.9 & 263.9 & 120 & 120 & 1240 & 960 & 44.0 \\
\hline \multicolumn{11}{|l|}{ Stream } \\
\hline Orbeton & 2014 & 41760 & 6.13 & $0 \uparrow$ & 179.1 & 0 & 60 & -60 & 970 & 0.0 \\
\hline \multicolumn{11}{|l|}{ Stream } \\
\hline Perham & 2010 & 46160 & 11.65 & 65.5 & 544.2 & 30 & 410 & 670 & 1560 & 44.0 \\
\hline \multicolumn{11}{|l|}{ Stream } \\
\hline Perham & 2013 & 23736 & 13.19 & 20 & 540.5 & 10 & 430 & 320 & 780 & 51.6 \\
\hline
\end{tabular}


Perham

$2014 \quad 31710$

4.78

$\begin{array}{llll}64.9 & 579.7 & 10 & 430\end{array}$

320780

44.1

Stream

Sandy River $\quad 2010 \quad 47940$

13.84

$1494.6 \quad 639.3$

$1600 \quad 570$

26102760

18.7

$(67 \mathrm{~km})$

Sandy River

$(73 \mathrm{~km})$

$\begin{array}{llllllllll}\text { Sandy River } \quad 2013 \quad 58232 & 11.94 & 200 & 1429.3 & 200 & 1280 & 200 & 3250 & 21.9\end{array}$

$(73 \mathrm{~km})$

$\begin{array}{lllllllllll}\text { Temple } & 2010 & 47940 & 29.31 & 1107.1 & 1054.4 & 250 & 560 & 4770 & 4630 & 33.8\end{array}$

Stream

$\begin{array}{lllllllllll}\text { Temple } & 2013 & 49553 & 14.86 & 866.2 & 1717.6 & 1100 & 490 & 2470 & 4790 & 47.5\end{array}$

Stream

Temple

$2014 \quad 41760$

2.45

$1003.6 \quad 892$

$1100 \quad 490$

$2470 \quad 3070$

46.9

Stream

Temple

$2015 \quad 14404$

25.44

1073.1914

$1100 \quad 490$

$2840 \quad 3530$

54.5

Stream

Temple

$2018 \quad 5350$

46.39

$320 \quad 331.9$

$320 \quad 110$

$320 \quad 1510$

8.5

Stream

Averages

35789

22.0

$444.6 \quad 649.4$

$403.2 \quad 403.7$

$1232.6 \quad 2135.3$

34.46

*Percent recovered determined by dividing the population estimate by the total eggs implanted.

¡No upstream dispersal reported for Orbeton 2014. 
Table 3. Multiple GLS regression results relating fry dispersal variable to a priori predictors.

Variables Value SE t-value P-value

(A) \% Upstream $(n=19, \mathrm{df}=18, \Delta \mathrm{AICc}=4.71)$

Intercept

2.51

0.170

$14.794<0.00001$

(B) Median downstream distance $(\mathrm{n}=19, \mathrm{df}=16 \Delta \mathrm{AICc}=2.84)$

Intercept

$$
4495.814
$$

378.349

$11.883<0.00001$

Stream velocity

$-356.345$

41.9481

$-8.495<0.00001$

Stream gradient

$-209.143$

28.021

$-7.464<0.00001$

(C) Maximum downstream distance $(\mathrm{n}=19, \mathrm{df}=16, \Delta \mathrm{AICc}=-1.27)$

Intercept

Stream velocity

Body length

$$
-5242.46
$$

703.747

90.021
367.272

119.250

5.121
$-14.274<0.00001$

$5.901<0.00001$

$17.577<0.00001$

(D) Median upstream distance $(\mathrm{n}=19, \mathrm{df}=17, \Delta \mathrm{AICc}=3.85)$

Intercept

Body length
$-119.028$

2.468
3.784

0.079
$-31.457<0.00001$

$31.457<0.00001$

(E) Maximum upstream distance $(\mathrm{n}=19, \mathrm{df}=16, \Delta \mathrm{AICc}=1.11)$

Intercept

Stream velocity

Body length

$$
-1142.423
$$$$
-379.106
$$

42.013

(F) Body Length $(\mathrm{n}=19, \mathrm{df}=16, \Delta \mathrm{AIC}=0.51)$
32.755

0.006
77.741

19.791

1.511
$-14.695<0.00001$

$-19.155<0.00001$

$27.811<0.00001$
Intercept

Stream velocity
4.183

0.002
$7.830<0.00001$

$3.151 \quad 0.002$ 


\begin{tabular}{lcccc} 
Egg mortality & 0.220 & 0.026 & 8.305 & $<0.00001$ \\
Log (Distance from redd) & 5.241 & 0.847 & 6.187 & $<0.00001$ \\
Position: Upstream & 3.986 & 0.791 & 5.042 & $<0.00001$ \\
Density & -0.051 & 0.012 & -4.431 & $<0.00001$ \\
\hline
\end{tabular}


Table 4. Comparison between a single- (stationary) or two- (mobile and stationary) parameter nonlinear equations (sensu Rodriguez 2002) to downstream dispersal distributions in seven Atlantic salmon populations. Kurtosis values are for each complete distribution (i.e. upstream and downstream).

\begin{tabular}{|c|c|c|c|c|c|c|}
\hline Population & Year & $\begin{array}{l}\text { AICc* } \\
\text { (Single) }\end{array}$ & $\begin{array}{l}\text { AICc } \\
\text { (Two) }\end{array}$ & Best fit & Kurtosis & Distribution \\
\hline Barker & 2010 & $\dagger$ & -16.870 & Two & -0.581 & Mesokurtic \\
\hline Cottle & 2010 & 68.216 & -14.596 & Two & 3.450 & Leptokurtic \\
\hline \multirow[t]{5}{*}{ Mt. Blue } & 2010 & 83.272 & 110.583 & Single & 4.761 & Leptokurtic \\
\hline & 2012 & 71.395 & 99.396 & Single & 1.960 & Mesokurtic \\
\hline & 2013 & $\dagger$ & 8.132 & Two & 0.344 & Mesokurtic \\
\hline & 2017 & 35.230 & $\dagger$ & Single & 0.078 & Mesokurtic \\
\hline & 2018 & 46.822 & $\dagger$ & Single & 2.882 & Mesokurtic \\
\hline Orbeton & 2014 & $\dagger$ & -14.898 & Two & 2.835 & Mesokurtic \\
\hline \multirow[t]{3}{*}{ Perham } & 2010 & $\dagger$ & -17.279 & Two & 0.778 & Mesokurtic \\
\hline & 2013 & $*$ & $*$ & $*$ & -1.105 & Mesokurtic \\
\hline & 2014 & $*$ & $*$ & $*$ & -1.241 & Mesokurtic \\
\hline \multirow[t]{3}{*}{ Sandy } & 2013 & 55.293 & 76.040 & Single & -1.266 & Mesokurtic \\
\hline & 2010 & 64.808 & $\dagger$ & Single & 0.594 & Mesokurtic \\
\hline & 2010 & 59.743 & $\dagger$ & Single & 0.021 & Mesokurtic \\
\hline \multirow[t]{2}{*}{ Temple } & 2010 & 61.827 & -34.671 & Two & 2.454 & Mesokurtic \\
\hline & 2013 & 50.940 & $\dagger$ & Single & 0.369 & Mesokurtic \\
\hline
\end{tabular}




\begin{tabular}{cccccc}
2014 & $*$ & $*$ & $*$ & 0.589 & Mesokurtic \\
2015 & $\dagger$ & $\mathbf{- 3 . 8 2 5}$ & Two & 0.948 & Mesokurtic \\
2018 & 64.376 & $\mathbf{- 1 5 . 6 2 4}$ & Two & 0.914 & Mesokurtic \\
\hline
\end{tabular}

* Denotes distributions that were excluded due to small sample size $(<3)$

$\uparrow$ Denotes overfitted models.

Bold denotes selected model. 


\section{Supplementary Methods}

Egg take:

Sea run adult Atlantic salmon were captured in the Penobscot River and held at Craig Brook National Fish Hatchery until spawning. They were moved to Green Lake National Fish Hatchery as eyed eggs and reared to adulthood. Each year Green Lake spawns 500 or more families of adults. Given that the salmon don't all spawn at the same time, the hatchery personnel spawn the broodstock in waves, as they mature. In a given season, they will spawn anywhere from 2-6 waves (i.e. takes). Each take is made up of a different number of families, that are fertilized at different times and, hence, vary in developmental stage. In the winter as each take reaches the eyed stage, the offspring are divided into samples destined for planting in multiple sites. Each sample of eggs will comprise a different number of potential families. For example, in 2017, Mt Blue eggs were composed of 230 families from a single take. In most cases, the sex ratio for spawning was a 1:1. For the age 4 females, the number of family groups are similar to the number of females as the hatchery personnel cross age 4 females with age 3 males. For age 3 females, the number of family groups may be reduced if the hatchery is short of age 4 males and therefore spawns some males twice. Any differences in the number of eggs transferred to the Kennebec Drainage and the Eyed Egg Take (Table S2) indicate that eggs were distributed to other programs and or mortality incurred after the initial enumeration.

All eyed eggs were counted and transferred from the hatchery in insulated shipping containers the afternoon prior to planting (Fig. S1). Each styrofoam shipping container ( $49 \mathrm{~cm} \mathrm{x}$ $42 \mathrm{~cm} \times 39 \mathrm{~cm}$ high) had six trays with four compartments. Each compartment was fitted with wetted cheese cloth, and eggs were placed on top. No eggs were placed in the bottom or the top tray. The bottom tray acts as a spacer to keep the eggs out of the water caused by melting ice 
which is located in the top tray. As trays were loaded, they were stacked in the container. When the container was full, the last tray on top was filled with ice and dampened with a small amount of water. Containers were held overnight at room temperature. Upon arrival the following day at the river, the eggs were removed from the shipping containers and placed in jugs of water to reduce the chance of freezing prior to burial.

In-stream incubation system:

The equipment used to bury the eggs was developed by the Maine Department of Marine Resources (MDMR) for large scale Atlantic salmon restoration (Fig. S2). The new In-Stream Incubation System has three components. A backpack carried a Honda WX15 four stroke 49cc water pump with a capacity of $272.5 \mathrm{~L} / \mathrm{min}$ attached to a $3.1 \mathrm{~cm}$ diameter standpipe with a flexible hose. A funnel was made of a $152 \mathrm{~mm}$ X $460 \mathrm{~mm}$ pipe attached to a reducer that brings the diameter down to a $360 \mathrm{~mm}$ long pipe, just large enough in diameter for the standpipe to fit inside. The standpipe was fitted with a hose clamp and rubber stopper to keep the pipe from protruding out of the bottom of the funnel. The funnel and standpipe, with the pump running, were inserted into the gravel to the desired depth. For this project we planted eggs $30 \mathrm{~cm}$ below the surface of the stream bed, within the normal range for Atlantic salmon (Bley 1987). When the depth was reached, the standpipe was removed from the funnel leaving it in the gravel. Three to five hundred eggs were then poured underwater into the funnel. When sufficient time has passed for the eggs to reach the lower end of the funnel, it was lifted several $\mathrm{cm}$, so that more eggs could be poured in. Two groups of eggs were deposited each time the funnel was inserted. The density of eggs ranged from 3,200-8,608 eggs/m2. Most of the eggs were planted by a single 
crew of 3-5 people. On several occasions each year, two crews were deployed due to the number of eggs that were ready for planting.

Wild reproduction:

Wild, naturally reared, adult Atlantic salmon captured in Waterville, Maine on the mainstem Kennebec River, were transported to the uppermost portion of the Sandy River $(96.86 \mathrm{~km})$ almost $30 \mathrm{~km}$ upstream of our study sites on the Sandy River. Annual redd surveys were conducted to map the subsequent distribution of natural Atlantic salmon nests. Other than a few instances of wild reproduction, eyed eggs are the only other Atlantic salmon life stage released into the drainage.

Studies used in Fig. 4:

The data used to model frequency distributions of Atlantic salmon fry in Fig. 4 were extracted from figures and tables using the 'digitize' function in the package CRAN (RStudio version 1.2.0.5033) and text from each specific study, then modeled using a violin plot built in ggplot2 (RStudio version 1.2.0.5033).

Egglishaw and Shackley (1973) implanted Atlantic salmon eggs into the Fender Burn in Perthshire, Scotland, a steep stream with multiple waterfalls and gorges. The number of fry were estimated using electroshocking units and blocking seines. The lower distribution was not used as fry were sprinkle stocked over a long distance, $20 \mathrm{~m}$ below a waterfall. Upper distribution distances were conservatively assigned so as to not inflate dispersal distances. Fry were recorded $120 \mathrm{~m}$ upstream and $810 \mathrm{~m}$ downstream. Eggs were planted below a gorge. 
Marty and Beall (1989) observed over $50 \%$ of surviving fry ( $75 \%$ of planted eggs) settling within 50m downstream from redds in Lapitxuri Experimental Stream, Saint-Pêe-surNivelle, France. Their results showed two waves of downstream dispersal. The first occurred before the onset of aggressive territorial behavior, soon after emergence, to fill useable space. The second, denoted as late emerging fry, were displaced by territoriality. They used box traps and electroshocking to determine dispersal distance and timing. Upstream dispersal was blocked by a net.

Beall et al. (1994) captured 1270 fry in 8 traps, each trap occupying 5\% of the total flow (7785 fry) in Lapitxuri Brook, a tributary to River Nivelle, Basque Coutry, France. 15000 eyed eggs were implanted, so the survival rate would be about 51\%. An estimated 6491 fry settled between traps and 32 fry settled past the last trap $(800 \mathrm{~m})$. No upstream dispersal was measured but estimated to be 57 fry. The highest density of fry was $90-150 \mathrm{~m}$ below the redd in a stretch of very similar habitat.

Crisp (1995) assessed dispersal of stocked Atlantic salmon fry in Bollihope Burn, Co. Durham, England. The author reported some fish dispersing up to $50 \mathrm{~m}$ upstream or $500 \mathrm{~m}$ downstream of the stocking point, but the majority remained close to the point of release (see Crisp 1995, Tables 1, 2, 3 and Fig. 1). Fry had to negotiate a concrete slab at a 14\% grade to access upstream habitat.

Webb et al. (2004) assessed natural emergence of Atlantic salmon fry, using microsatellite DNA profiling (see Webb et al. Table 2, Fig. 2). The author reported densities of families in each sector of the main study reach. Three redds were planted on the same location, one was a short distance downstream. No fry were caught more than $940 \mathrm{~m}$ downstream or $90 \mathrm{~m}$ upstream of its stocking point. Only families F5,6, and 7 were used (Table 2, Fig. 2) 
Brodeur (2006) quantified the dispersal of Atlantic salmon fry via snorkel surveys. Microsatellite markers were used ( $78 \%$ estimated correctness probability) to assess the localscale distribution patterns of 81 juvenile Atlantic salmon in Catamaran Brook, a tributary to the Little Southwest Miramichi River, New Brunswick. Fry distributions ranged from 9-154m upstream and 50-955m downstream, with a median dispersal distance of $154 \mathrm{~m}$ upstream and 542m downstream (Fig. 2.4.).

Brunsdon et al. (2017) manipulated densities of Atlantic salmon fry in the Boquet River, NY, to evaluate the effects of clumped- (releasing all the fish at one location) and dispersedstocking (releasing the fish evenly over a complete reach) treatments on habitat use, dispersal, growth, and survival across 14 rivers. They documented "greater than expected" mobility of fish in clumped-stocking reaches; fry dispersed up to $1600 \mathrm{~m}$, with $41 \%$ moving over $200 \mathrm{~m}$ downstream. Upstream sampling terminated at 50m due to sampling design. 


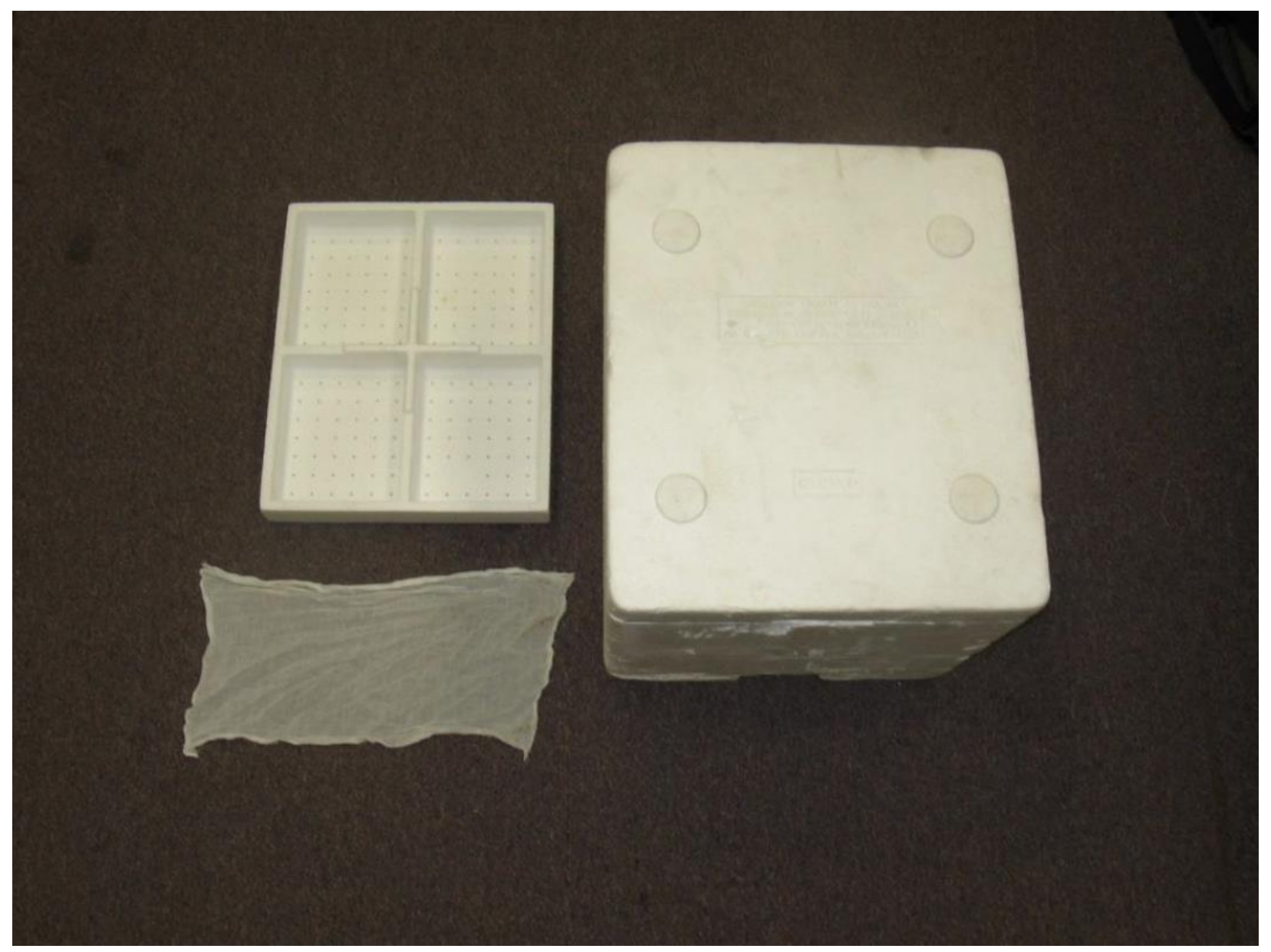

Fig S1. Insulated Styrofoam shipping container (right) used to transport eyed Atlantic salmon eggs from the Green Lake National Fish Hatchery to implant sites. One of six four-compartment trays (top left), used to stack eggs in the shipping container. One wetted cheese cloth (bottom left), used to cover each tray. 


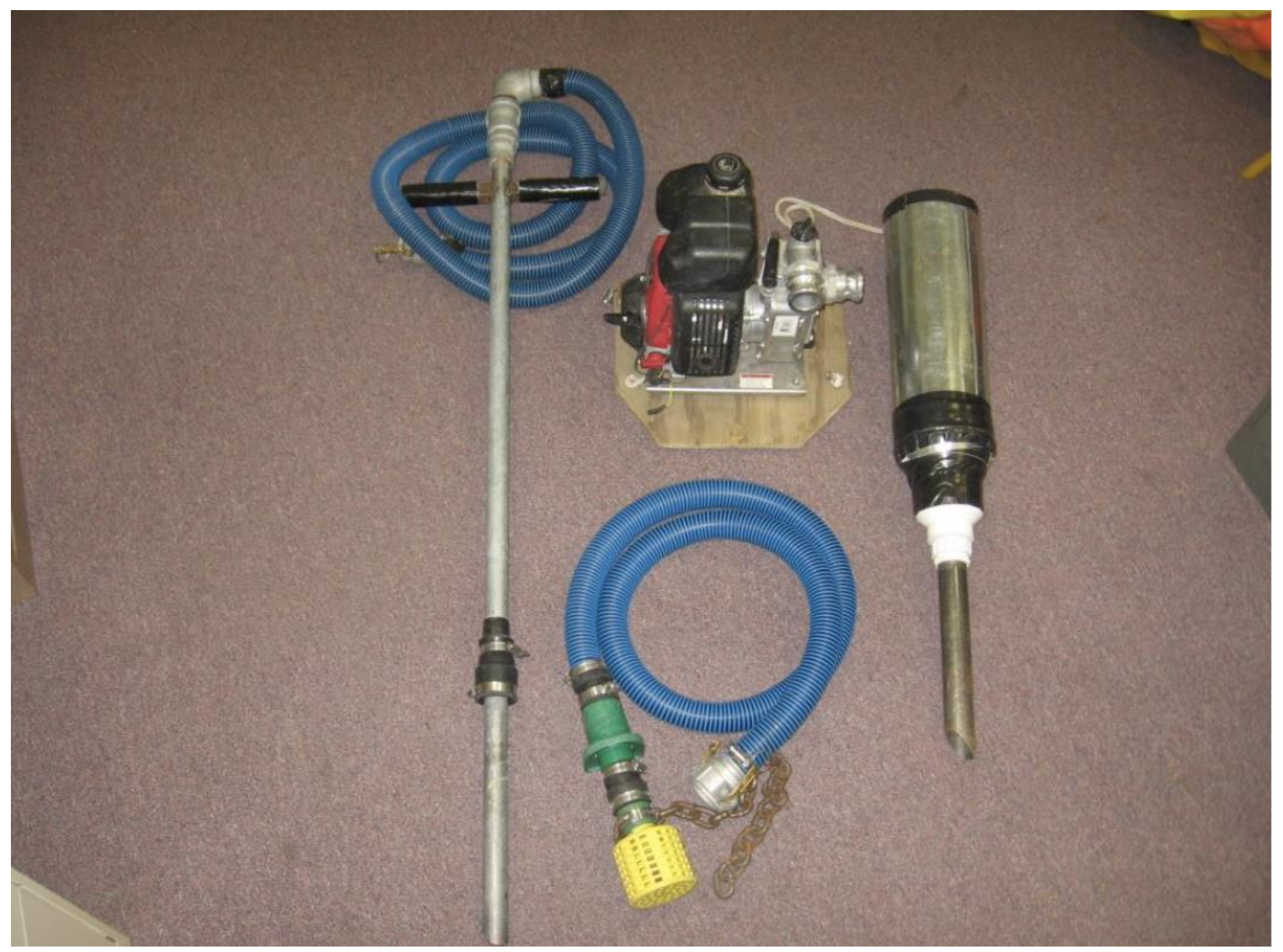

Fig. S2. Maine Department of Marine Resources (MDMR) In-Stream Incubation System. Honda WX15 four stroke 49cc water pump (middle top), $3.1 \mathrm{~cm}$ diameter standpipe with a flexible hose (left), intake hose for pump with debris guard (middle bottom), and metal funnel for receiving standpipe and implanting eggs (right). 


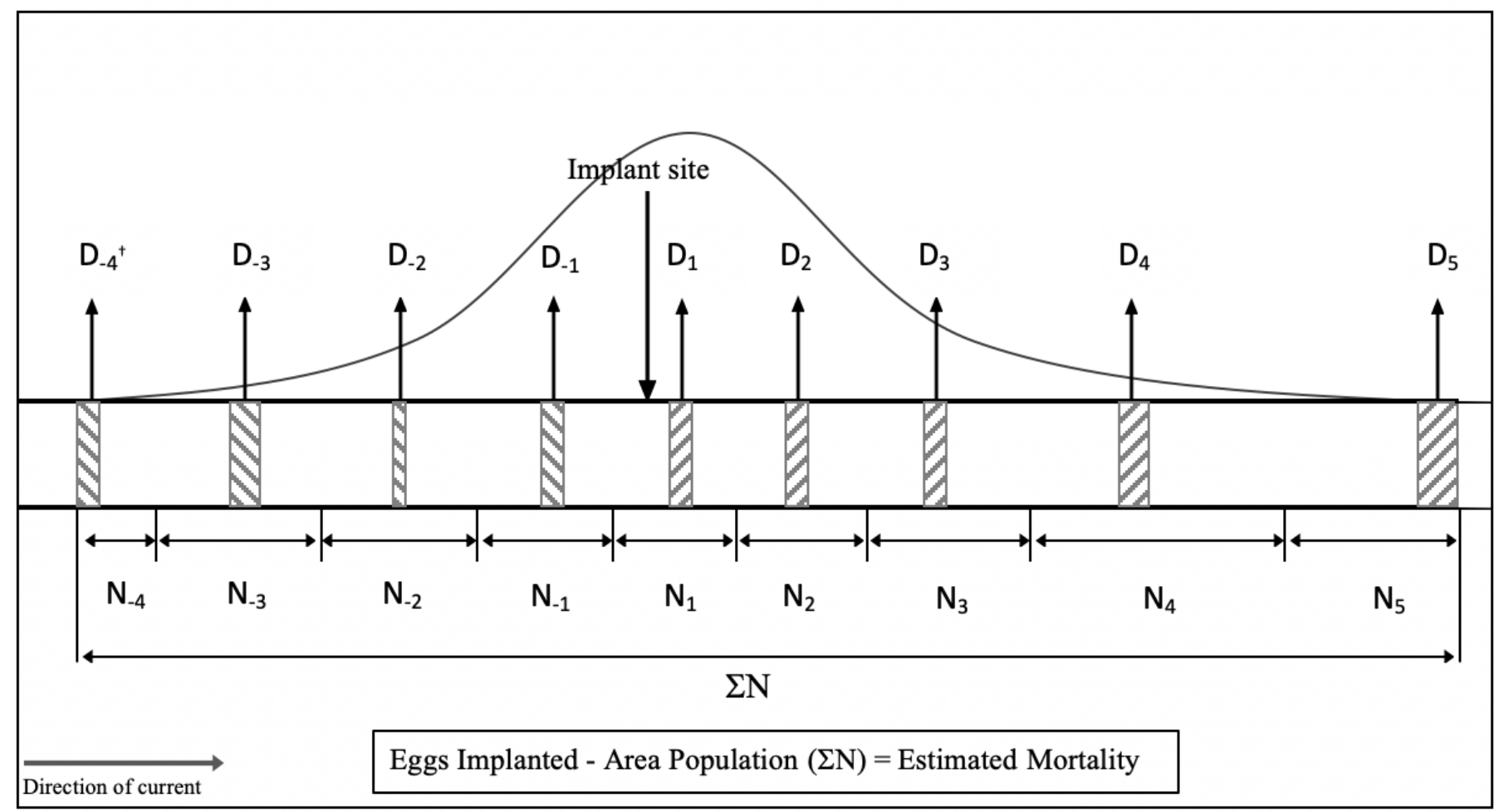

Fig. S3. Schematic of the typical sampling plan. $\mathrm{D}_{\#}=$ density estimate from CPUE electroshocking event. $\mathrm{N} \#=$ Population estimate for shocking reach and distance between reaches. † Negative subscript denotes upstream position. 


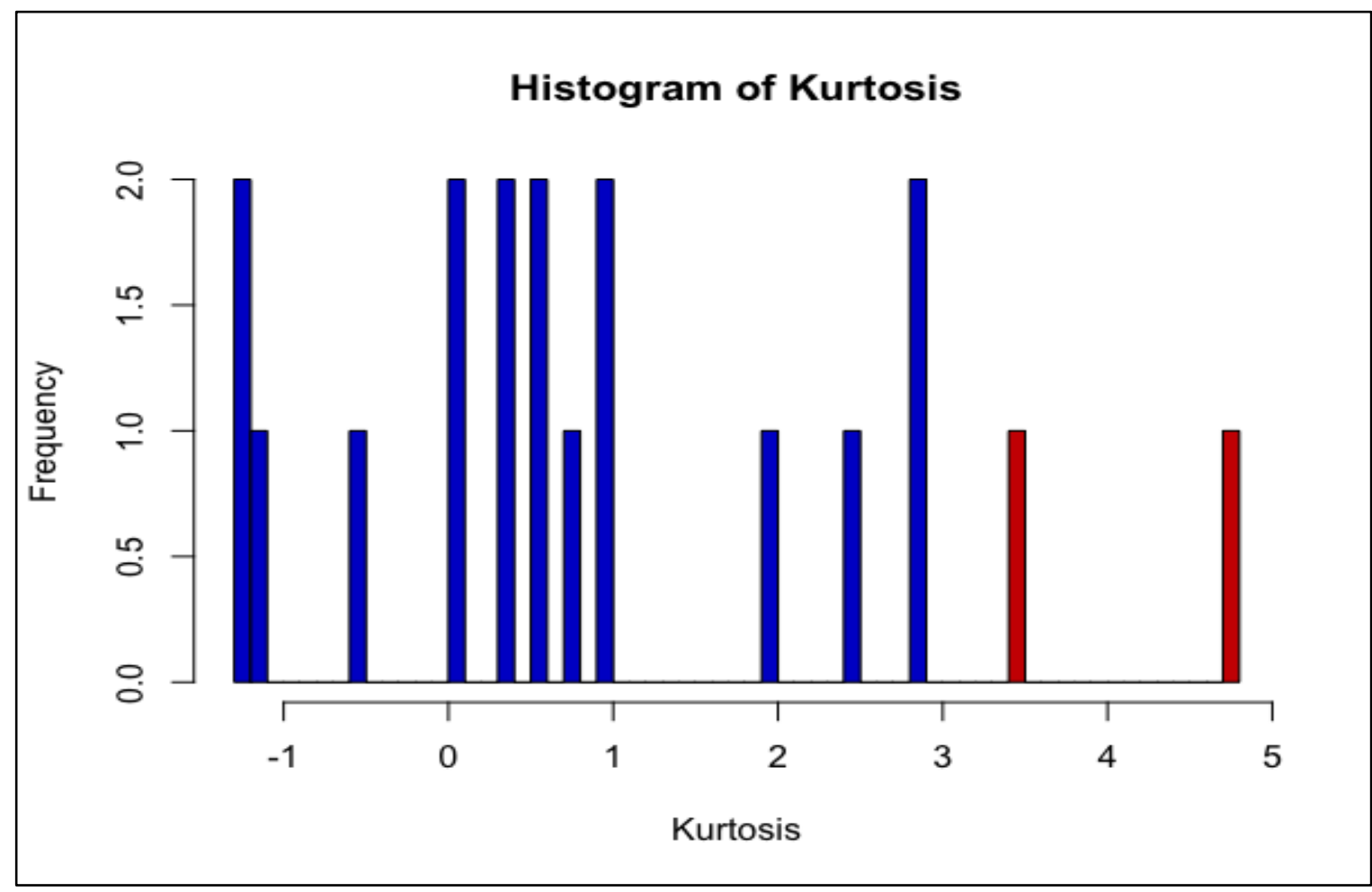

Fig. S4. Histogram of Kurtosis values. Blue indicates the frequency of normal distributions; red indicates the frequency of leptokurtic distributions. 
Table S1. Number and size of sampling sites in each stream.

$\alpha$ Area reported in meters squared, width reported in meters

\begin{tabular}{|c|c|c|c|c|}
\hline \multirow[b]{2}{*}{ Stream } & \multirow[b]{2}{*}{ Year } & \multicolumn{3}{|c|}{ Total area } \\
\hline & & Width (m) & $(\mathrm{m} 2)$ & \# of sites \\
\hline Temple & 2010 & 7.12 & 1235.67 & 11 \\
\hline Sandy 73 & 2010 & 22.8 & 1356.51 & 9 \\
\hline Sandy 67 & 2010 & 18.62 & 1514.61 & 12 \\
\hline Cottle & 2010 & 4.58 & 634.96 & 7 \\
\hline Mt. Blue & 2010 & 7.42 & 1607.64 & 13 \\
\hline Perham & 2010 & 7.28 & 847.02 & 7 \\
\hline Barker & 2010 & 4.48 & 556.14 & 6 \\
\hline Mt. Blue & 2012 & 6.85 & 1005 & 9 \\
\hline Perham & 2013 & 9.28 & 520 & 6 \\
\hline Mt. Blue & 2013 & 8.22 & 642 & 7 \\
\hline Sandy 73 & 2013 & 27.74 & 1249 & 11 \\
\hline Temple & 2013 & 10.31 & 1075 & 11 \\
\hline Orbeton & 2014 & 10.66 & 568 & 6 \\
\hline Perham & 2014 & 8.09 & 467 & 6 \\
\hline Temple & 2014 & 8.79 & 633 & 7 \\
\hline Temple & 2015 & 9.63 & 1181 & 11 \\
\hline Mt. Blue & 2017 & 7.08 & 1465.95 & 12 \\
\hline
\end{tabular}




\begin{tabular}{lcccc} 
Temple & 2018 & 6.78 & 860.68 & 7 \\
Mt. Blue & 2018 & 7.86 & 1550.87 & 15 \\
\hline
\end{tabular}


Table S2. Details about egg sampling in each year.

\begin{tabular}{|c|c|c|c|c|c|c|c|c|}
\hline $\begin{array}{l}\text { Stock } \\
\text { Year }\end{array}$ & $\begin{array}{l}\text { Spawn } \\
\text { Year }\end{array}$ & Take Date & Take & Females & $\begin{array}{l}\text { Age- } \\
\text { Class }\end{array}$ & $\begin{array}{l}\text { Date of } \\
\text { Stripping }\end{array}$ & $\begin{array}{l}\text { No. } \\
\text { Transferred } \\
\text { to Kennebec }\end{array}$ & $\begin{array}{l}\text { No.Eyed } \\
\text { Eggs After } \\
\text { Sorting }\end{array}$ \\
\hline 2010 & 2009 & $11 / 4 / 09$ & 1 & 59 & 4 & $12 / 18 / 09$ & & 83,660 \\
\hline 2010 & 2009 & $11 / 9 / 09$ & 2 & 147 & 4 & $1 / 5 / 10$ & 535,500 & 259,931 \\
\hline 2010 & 2009 & $11 / 17 / 09$ & 3 & 106 & 4 & $1 / 28 / 10$ & & 234,495 \\
\hline 2012 & 2011 & $11 / 15 / 11$ & 1 & 54 & 4 & $1 / 16 / 12$ & 137,540 & 144,100 \\
\hline 2012 & 2011 & $11 / 21-22 / 2012$ & 2 & 297 & 4 & $2 / 2-3 / 2012$ & 773,349 & 789,202 \\
\hline 2013 & 2012 & $11 / 19 / 12$ & 1 & 13 & 4 & $2 / 12 / 13$ & 15,758 & 19,758 \\
\hline 2013 & 2012 & $11 / 27 / 12$ & 2 & 129 & 4 & $2 / 25 / 13$ & 334,015 & 339,891 \\
\hline 2013 & 2012 & $12 / 3 / 12$ & $3 a+b$ & 210 & 4 & $3 / 8 / 13$ & 304,309 & 462,096 \\
\hline 2014 & 2013 & $11 / 13 / 13$ & 1 & 35 & 4 & $2 / 4 / 14$ & 75,432 & 90,272 \\
\hline 2014 & 2013 & $11 / 19 / 13$ & $2 \mathrm{a}$ & 151 & 4 & $2 / 18-19 / 2014$ & 415,773 & 493,197 \\
\hline 2014 & 2013 & $11 / 20 / 13$ & $2 b$ & 126 & 3 & $2 / 20 / 14$ & 213,293 & 214,871 \\
\hline 2014 & 2013 & $11 / 26 / 13$ & 3 & 205 & 4 & $3 / 3-4 / 2014$ & 446,832 & 546,592 \\
\hline 2015 & 2014 & $11 / 19 / 14$ & $1 b$ & 16 & 3 & $2 / 12 / 15$ & 23,696 & 27,696 \\
\hline 2015 & 2014 & $11 / 26 / 14$ & $2 b$ & 121 & 3 & $2 / 24 / 15$ & 181,507 & 181,707 \\
\hline 2015 & 2014 & $12 / 1 / 14$ & $3 b$ & 66 & 3 & $3 / 3 / 15$ & 69,384 & 95,844 \\
\hline 2017 & 2016 & $11 / 15 / 16$ & 1 & 4 & 4 & $1 / 24 / 17$ & 938 & 8,251 \\
\hline 2017 & 2016 & $11 / 16 / 16$ & $1 b$ & 20 & 3 & $1 / 24 / 17$ & 17,608 & 23,408 \\
\hline
\end{tabular}




$\begin{array}{lllllllll}2017 & 2016 & 11 / 22 / 16 & 2 b & 230 & 3 & 2 / 8 / 17 & 328,592 & 328,992 \\ 2017 & 2016 & 11 / 30 / 16 & 3 b & 93 & 3 & 2 / 24 / 17 & 99,968 & 127,616 \\ 2018 & 2017 & 11 / 21 / 17 & 1 & 61 & 4 & 2 / 9 / 18 & 108,900 & 173,700 \\ 2018 & 2017 & 11 / 27 / 17 & 1 b & 30 & 3 & 2 / 20 / 18 & 39,321 & 39,321 \\ 2018 & 2017 & 11 / 28 / 17 & 2.1 & 148 & 4 & 2 / 21 / 18 & 318,273 & 436,729 \\ 2018 & 2017 & 11 / 29 / 17 & 2.2 & 163 & 4 & 2 / 22 / 18 & 237,300 & 443,414 \\ 2018 & 2017 & 12 / 5 / 17 & 2 b & 164 & 3 & 3 / 2 / 18 & 239,232 & 239,632\end{array}$


Table S3. Summary of wild Atlantic salmon activity in headwaters of Kennebec River

\begin{tabular}{lccl}
\hline & Number of & & Distance to \\
Year & adults moved & \# redds & implant $(\mathrm{km})$ \\
\hline 2010 & 5 & 0 & N/A \\
2011 & 64 & 27 & N/A* \\
2012 & 5 & 2 & N/A* \\
2013 & 8 & 0 & N/A \\
2014 & 18 & 5 & 0.4 \\
2015 & 31 & 21 & 11.95 \\
2016 & 39 & 24 & N/A** \\
2017 & 36 & 3 & N/A* \\
2018 & 11 & 3 & N/A* \\
\hline
\end{tabular}

*No redds in river with implanting sites **No implant sites this year 
Table S4. Predictions about how environmental variables will affect Atlantic salmon fry dispersal. ${ }^{\alpha} \mathrm{SC}=$ Swimming capacity; DD = Density dependence

\begin{tabular}{|c|c|c|c|}
\hline Variable & Predictions & Rationale* & Results \\
\hline$\%$ Moving & Downstream > upstream & $\mathrm{SC}$ & True \\
\hline \multirow[t]{7}{*}{$\%$ Moving upstream } & Velocity: - & $\mathrm{SC}$ & True \\
\hline & Gradient: - & $\mathrm{SC}$ & True \\
\hline & Stream Width: - & DD & True \\
\hline & Discharge: - & $\mathrm{SC}$ & True: \\
\hline & Body size: + & $\mathrm{DD}, \mathrm{SC}$ & False \\
\hline & Number of eggs: + & DD & False \\
\hline & Egg mortality: - & $\mathrm{DD}$ & False \\
\hline \multirow[t]{7}{*}{ Distance downstream } & Velocity: + & $\mathrm{SC}$ & True \\
\hline & Gradient: + & $\mathrm{SC}$ & False \\
\hline & Stream Width: - & DD & False \\
\hline & Discharge: + & $\mathrm{SC}$ & True $\$$ \\
\hline & Body size: + & DD & True: \\
\hline & Number of eggs: + & DD & True $_{*}$ \\
\hline & Egg mortality: - & DD & True \\
\hline
\end{tabular}
Distance Upstream
Velocity: -
$\mathrm{SC}$
False 


$\begin{array}{llc}\text { Gradient: - } & \text { SC } & \text { True } \\ \text { Stream Width: - } & \text { DD } & \text { False: } \\ \text { Discharge: - } & \text { SC } & \text { True: } \\ \text { Body size: }+ & \text { DD, SC } & \text { True: } \\ \text { Number of eggs: }+ & \text { DD } & \text { True: } \\ \text { Egg mortality: }- & \text { DD } & \text { True }\end{array}$




\section{References}

Araki, H., Berejikian, B. A., Ford, M. J., and Blouin, M. S. 2008. Fitness of hatchery-reared salmonids in the wild. Evol Appl. 1(2): 342-355. doi:10.1111/j.1752-4571.2008.00026.x.

Armstrong, J. D., Kemp, P. S., Kennedy, G. J. A., Ladle, M., and Milner, N. J. 2003. Habitat requirements of Atlantic salmon and brown trout in rivers and streams. Fish. Res. 62(2): 143-170. doi:10.1016/S0165-7836(02)00160-1.

Beall, E., Dumas, J., Claireaux, D., Barriere, L., and Marty, C. 1994. Dispersal patterns and survival of Atlantic salmon (Salmo salar L.) juveniles in a nursery stream. ICES J. Mar. Sci. 51(1):1-9. doi:10.1006/jmsc.1994.1001.

Bley, P. W. 1987. Age, growth, mortality of juvenile Atlantic salmon in streams: a review. U. S. Fish and Wildlife Service. Department of the Interior. Biological Report, 87(4).

Brodeur, N. N. 2006. Dispersion Patterns of kin in young-of-year Atlantic salmon (Salmo salar L.) in Catamaran Brook, New Brunswick. M.Sc. thesis, Department of Biology, Concordia University, Montreal.

Brunsdon E. B., Fraser D. J., Ardren W. R., and Grant J. W. A. 2017. Dispersal and densitydependent growth of Atlantic salmon (Salmo salar) juveniles: clumped versus dispersed stocking. Can. J. Fish. Aquat. Sci. 74(9):1337-1347. doi:10.1139/cjfas-2015-0488.

Burnham, K. P., and Anderson, D. R. 2004. Multimodel Inference: Understanding AIC and BIC in Model Selection. Fort Collins, CO: Colorado Cooperative Fish and Wildlife Research Unit (USGS-BRD).

Clobert, J., Baguette, M., Benton, T. G., and Bullock, J. M. 2012. Dispersal Ecology and Evolution. Oxford: Oxford University Press.

Crisp, D.T. 1995. Dispersal and growth rate of 0-group salmon (Salmo salar L.) from point- 
stocking together with some information from scatter-stocking. Ecol. Freshw. Fish. 4(1):1-8. doi:10.1111/j.1600-0633.1995.tb00021.x.

De Bie, T., Meester, L., Brendonck, L., Martens, K., Goddeeris, B., Ercken, D., Hampel, H., Denys, L., Vanhecke, L., and Gucht, K. 2012. Body size and dispersal mode as key traits determining metacommunity structure of aquatic organisms. Ecol. Lett. 15(7):740-747. doi:10.1111/j.1461-0248.2012.01794.x.

Dittman, A. H., Pearsons, T. N., May, D., Couture, R. B., and Noakes, D. L. G. 2015. Imprinting of Hatchery-Reared Salmon to Targeted Spawning Locations: A New Embryonic Imprinting Paradigm for Hatchery Programs. Fish. 40(3):114-123. doi:10.1080/03632415.2015.1007206.

Drakou, E. G., Bobori, D. C., Kallimanis, A. S., Mazaris, A. D., Sgardelis, S. P., and Pantis. J. D. 2009. Freshwater fish community structured more by dispersal limitation than by environmental heterogeneity. Ecol. Freshwat. Fish, 18: 369-379. doi: 10.1111/j.16000633.2009.00354.x.

Egglishaw, H. J., and Shackley, P. E. 1973. An experiment on faster growth of salmon (Salmo salar L.) in a Scottish stream. J. Fish Biol. 5(2):197-204. doi:10.1111/j.10958649.1973.tb04448.x.

Egglishaw, H. J., and Shackley, P. E. 1980. Survival and growth of salmon (Salmo salar L.) planted in a Scottish stream. J. Fish Biol. 16(5):565-584. doi:10.1111/j.10958649.1980.tb03734.x.

Einum, S., and Nislow, K. H. 2005. Local-scale density-dependent survival of mobile organisms in continuous habitats: An experimental test using Atlantic salmon. Oecologia, 143(2):203-210. doi:10.1007/s00442-004-1793-y. 
Einum, S., Robertsen, G., Nislow, K. H., McKelvey, S., and Armstrong, J. D. 2011. The spatial scale of density-dependent growth and implications for dispersal from nests in juvenile Atlantic salmon. Oecologia (Berl.), 165(4):959-969. doi:10.1007/ s00442-010-1794-y.

Einum, S., Finstad, A.G., Robertsen, G., Nislow, K. H., McKelvey, S., and Armstrong, J. D. 2012. Natal movement in juvenile Atlantic salmon: a body size-dependent strategy? Popul. Ecol. 54(2)285-294. doi: 10.1007/s10144-011-0296-Z.

Elliott, J. M. 1966. Downstream movements of trout fry (Salmo trutta) in a Dartmoor stream. J. Fish. Res. Board Can. 23(1):157-159. doi:10.1139/f66-014.

Elliott, J. M. 1994. Quantitative ecology and the brown trout. Oxford University Press, Oxford.

Ewers, R. M., and R. K. Didham. 2006. Confounding factors in the detection of species responses to habitat fragmentation. Biol. Rev., 81:117-142. doi:10.1017/S1464793105006949

Foldvik, A., Einum, S., and Finstad, A. G. 2017. Spatial diffusion modelling of juvenile Atlantic salmon (Salmo salar) shows ontogenetic increase in movement rates. Can. J. Fish. Aquat. Sci. 74(2):202-207. doi:10.1139/cjfas-2015-0315.

Fraser, D. F., Gilliam, J. F., Daley, M. J., Le, A. N. and Skalski, G. T. 2001. Explaining leptokurtic movement distributions: Intra-population variation in boldness and exploration. Am. Nat. 158(2):124-135. doi:10.1086/321307.

George, D., and Mallery, P. 2010. SPSS for Windows Step by Step: A Simple Guide and Reference 18.0 Update.

Gerking, S. D. 1959. The restricted movement of fish populations. Biol. Rev. 34(2):221242. doi:10.1111/j.1469-185X.1959.tb01289.x

Gibert, J. P. 2016. The effect of phenotypic variation on metapopulation persistence. Popul. Ecol. 
58:345-355. doi:10.1007/s10144-016-0548-z.

Girard, I. L., Grant, J. W. A., and Steingrímsson, S. O. 2004. Foraging, growth, and loss rate of young-of-the-year Atlantic salmon (Salmo salar) in relation to habitat use in Catamaran Brook, New Brunswick. Can. J. Fish. Aquat. Sci. 61(12): 2339-2349.

Gomez, J. M., and Zamora, R. 1999. Generalization vs. specialization in the pollination systems of Hormathophylla spinosa (Cruciferae). Ecology, 80(3):796-805. doi:10.1890/00129658(1999)080[0796:GVSITP]2.0.CO;2.

Gowan, C., Young, M. K., Fausch, K. D., and Riley, S. C. 1994. Restricted movement in resident stream salmonids: A paradigm lost. Can. J. Fish. Aquat. Sci., 51(11):2626-2637. doi:10.1139/f94-262.

Grant, J. W. A., and Imre, I. 2005. Patterns of density-dependent growth in juvenile streamdwelling salmonids. J. Fish Biol. 67(SB):100-110. doi:10.1111/j.10958649.2005.00916.x.

Grossman, G. D., Nuhfer, A., Zorn, T., Sundin, G., and Alexander, G. 2012. Population regulation of brook trout (Salvelinus fontinalis) in hunt creek, Michigan: A 50-year study. Freshw. Biol. 57(7):1434-1448. Doi:10.1111/j.1365-2427.2012.02806.x.

Gustafson-Greenwood, K.I., and Moring, J.R. 1990. Territory size and distribution of newlyemerged Atlantic salmon (Salmo salar). Hydrobiologia, 206:125-131. doi:10.1007/BF00018638.

Hedger, R. D., Diserud, O. H., Sandlund, O. T., Saksgård, L., Ugedal, O., and Bremset, G. 2018. Bias in estimates of electrofishing capture probability of juvenile Atlantic salmon. Fish. Res. 208:286-295. doi:10.1016/j.fishres.2018.08.005.

Heggenes, J. 1990. Habitat utilization and preferences in juvenile Atlantic salmon (Salmo salar) 
In streams. Regul. Rivers Res. Manage. 5(4): 341-354. doi:10.1111/j.13652427.2012.02806.x.

Heggenes, J. and Dokk, J. G. 2001. Contrasting temperatures, waterflows, and light: seasonal habitat selection by young Atlantic salmon and brown trout in a boreonemoral river. Regul. Rivers Res. Manage. 17(6):623-635. doi:10.1002/rrr.620.

Hesthagen, T. 1988. Movements of brown trout (Salmo trutta) and juvenile Atlantic salmon (Salmo salar) in a coastal stream in northern Norway. J. Fish. Biol. 32(5): 639-653. doi:10.1111/j.1095-8649.1988.tb05404.x

Hudy, M., Coombs, J. A., Nislow, K. H., and Letcher, B. H. 2010. Dispersal and within-stream spatial population structure of brook trout revealed by pedigree reconstruction. Trans. Am. Fish. Soc. 139(5):1276-1287. doi:10.1577/T10-027.1.

Jelks, H. L., Walsh, S. J., Burkhead, N. M., Contreras-Balderas, S., Diaz-Pardo, E., Hendrickson, D. A., Lyons, J., Mandrak, N. E., McCormick, F., Nelson, J. S., Platania, S. P., Porter, B. A., Renaud, C. B., Schmitter-Soto, J. J., Taylor, E. B., and Warren, M. L. J. 2008. Conservation status of imperiled North American freshwater and diadromous fishes. Fisheries, 33(8):372-407. doi:10.1577/1548-8446-33.8.372.

Jokikokko, E. 1999. Density of brown trout (Salmo trutta L.) and Atlantic salmon (Salmo salar L.) parr after point and scatter stocking of fry. Fish. Manag. Ecol. 6(6):475-486. doi:10.1046/j.1365-2400.1999.00163.x.

Jonsson, B., Jonsson, N. and Hansen, L. P. 2003. Atlantic salmon straying from the River Imsa. J. Fish Biol 62:641-657. doi:10.1046/j.1095-8649.2003.00053.x. 
Louhi, P., Mäki-Petäys, A., and Erkinaro, J. 2008. Spawning habitat of Atlantic salmon and brown trout: general criteria and intragravel factors. River Res. Appl. 24(3):330-339. doi:10.1002/rra.1072.

Maine Department of Marine Resources (MDMR). 2014. Kennebec River Atlantic Salmon Interim Management Plan 2015-2020. Augusta, ME: Maine Department of Marine Resources.

Marty, C., and Beall, E. 1989. Modalites spatio-temporelles da la dispersion d'alevins de saumon Atlantique (Salmo salar L.) a I'emergence. Revue des Sciences de 1'eau, 2(4):831-846. doi:10.1002/iroh.19860710308.

Matte, J-M, Fraser, D. J., and Grant, J. W. A. 2020. Population variation in density-dependent growth, mortality and their trade-off in a stream fish. J. Anim. Ecol. 89(2):541-552. doi:10.1111/1365-2656.13124.

Milot, E., Perrier, C., Papillon, L., Dodson, J. J., and Bernatchez, L. 2013. Reduced fitness of Atlantic salmon released in the wild after one generation of captive breeding. Evol Appl. 6(3):472-485. doi:10.1111/eva.12028.

Niemelä, E., Julkunen, M., and Erkinaro, J. 2000. Quantitative electrofishing for juvenile salmon densities: assessment of the catchability during a long-term monitoring programme. Fish. Res. 48(1):15-22. doi:10.1016/S0165-7836(00)00113-2.

Ottaway, E. M., and Clarke, A. 1981. A preliminary investigation into the vulnerability of young trout (Salmo trutta L.) and Atlantic salmon (Salmo salar L.) to downstream displacement by high water velocities. J. Fish Biol. 19(2):135-145. doi:10.1111/j.10958649.1981.tb05818.x.

Paradis, E., Baillie, S. R., Sutherland, W. L., and Gregory, R. D. 1998. Patterns of natal and 
breeding dispersal in birds. J. Anim. Ecol. 67(4):518-536. doi:10.1046/j.13652656.1998.00215.x.

Porter; J. H., and Dooley, J. L. Jr. 1993. Animal dispersal patterns: a reassessment of simple mathematical models. Ecology, 74(8):2436-2443. doi:10.2307/1939594.

Radinger, J., and Wolter, C. 2014. Patterns and predictors of fish dispersal in rivers. Fish. Fish. 15(3): 456-473. doi:10.1111/faf.12028.

Rasmussen, J. E., and Belk, M. C. 2017. Individual movement of stream fishes: Linking ecological drivers with evolutionary processes. Rev. Fish. Sci. and Aquac. 25(1):70-83. doi:10.1080/23308249.2016.1232697.

Reid, J. E., and Chaput, G. 2012. Spawning history influence on fecundity, egg size, and egg survival of Atlantic salmon (Salmo salar) from the Miramichi River, New Brunswick, Canada. ICES J. Mar. Sci. 69(9):1678-1685. doi:10.1093/icesjms/fss091.

Ries, K. G., III, Newson J. K., Smith, M. J., Guthrie, J. D., Steeves, P. A., Haluska, T. L., Kolb, K. R., Thompson, R. F., Santoro, R. D., and Vraga, H. W., 2017, StreamStats, version 4: U.S. Geological Survey Fact 2017-3046, 4 p. doi:10.3133/fs20173046.

Rodriguez, M. A. 2002. Restricted movement in stream fish: the paradigm is incomplete, not lost. Ecology, 83(1):1-13. doi:10.2307/2680115.

Ronce, O. 2007. How does it feel to be like a rolling stone? Ten questions about dispersal evolution. Annu. Rev. Ecol. Evol. Syst. 38(1):231-253. doi:10.1146/annurev.ecolsys.38.091206.095611.

Roy, M. L., Roy, A. G., Grant, J. W. A, and Bergeron, N. E. 2013. Individual variability in the movement behaviour of juvenile Atlantic salmon. Can. J. Fish. Aquat. Sci. 70(2):339347. doi:10.1139/cjfas-2012-0234. 
Skalski, G. T. and Gilliam, J. F. 2000. Modelling diffusive spread in a heterogeneous population: a movement study with stream fish. Ecology, 81(6):1685-1700. doi:10.1890/00129658(2000)081[1685:MDSIAH]2.0.CO;2.

Šlapanský, L., Janáč, M., Roche, K., and Jurajda, P. 2020. Round goby movement patterns in a non-navigable river. Can. J. Fish. Aquat. Sci. 77(3):475-483. doi:10.1139/cjfas-20180488 .

Teichert, M. A. K., Foldvik, A., Forseth, T., Ugedal, O., Einum, S., Finstad, A. G., Hedger, R. D., and Bellier, E. 2011. Effects of spawning distribution on juvenile Atlantic salmon (Salmo salar) density and growth. Can. J. Fish. Aquat. Sci. 68(1):43-50. doi: 10.1139/F10-141.

Turchin, P. 1998. Quantitative Analysis of Movement: Measuring and Modelling Population Redistribution of Plants and Animals. Sinauer Associates, Sunderland, MA.

Queller, D. C., and Goodnight, K. F. 1989. Estimating relatedness using genetic markers. Evolution, 43(2):258-275. doi:10.2307/ 2409206.

Vøllestad, L. A., Serbezov, D., Bass, A., Bernatchez, L., Olsen, E. M., and Taugbøl, A. 2012. Small-scale dispersal and population structure in stream-living brown trout (Salmo trutta) inferred by mark-recapture, pedigree reconstruction, and population genetics. Can. J. Fish. Aquat. Sci. 69(9):1513-1524. doi:10.1139/f2012-073.

Webb, J. H., Fryer, R. J., Taggart, J. B., Thompson, C. E., and Youngson, A. F. 2001. Dispersion of Atlantic salmon (Salmo salar) fry from competing families as revealed by DNA profiling. Can. J. Fish. Aquat. Sci. 58(12):2386-2395. doi:10.1139/cjfas-58-12-2386.

Yeakel, J. D., Gibert, J. P., Gross, T., Westley, P. A. H., and Moore, J. W. 2018. Eco- 
evolutionary dynamics, density-dependent dispersal and collective behaviour:

implications for salmon metapopulation robustness. Phil. Trans. R. Soc. B. 373(1746). doi:10.1098/rstb.2017.0018.

Zuur, A. F., Leno, E. N., and Elphick, C. S. 2010. A protocol for data exploration to avoid common statistical problems. Methods Ecol. Evol. 1(1):3-14. doi: 10.1111/j.2041210X.2009.00001.x. 